\title{
38. GEOLOGICAL EVOLUTION OF THE NAURU BASIN, AND REGIONAL IMPLICATIONS1,2
}

\author{
Roger L. Larson, Graduate School of Oceanography, University of Rhode Island, Kingston, Rhode Island \\ and \\ Seymour O. Schlanger, Hawaii Institute of Geophysics, University of Hawaii, Honolulu, Hawaii
}

\section{INTRODUCTION}

Leg 61 originally was planned as a study of sedimentary, paleoceanographic, biostratigraphic, petrologic, magnetic, and tectonic problems in the western Pacific ranging back to Late Jurassic time. To this end, Site 462 was chosen in the northern Nauru Basin as a location in deep water with a thick sedimentary section that rests on some of the demonstrably oldest oceanic crust in the Pacific Basin. The claim of Late Jurassic age for the oceanic crust of the northern Nauru Basin has been brought into question by penetration of 504 meters of mid- to Late Cretaceous basalt sills and flows and sediments and the lack of Jurassic material at the bottom of DSDP Hole 462A. Because interpretations of this Cretaceous volcanic complex are strongly biased by beliefs about the nature and age of the underlying oceanic crust, we believe it important to review here the evidence for the original claim of a Late Jurassic basement age for the northern Nauru Basin.

\section{Basement Age of the Nauru Basin}

Although strong inferential arguments can be made based on the geology of Site 462 , the claim of a Late Jurassic basement age at this location rests, as is usual in ocean-crust dating, on the interpretation of magneticanomaly profiles in this area. The original magneticanomaly interpretations were made by Larson (1976), who correlated Late Jurassic magnetic anomalies M16 to M25 in the Nauru Basin. These lineations trend eastnortheast across the basin, and increase in age from south to north. A detail from Larson (1976; fig. 2) is shown in Figure 1 to illustrate the definition and detail of the oldest part of this sequence in the northern Nauru Basin. Figure 1 illustrates the "regional" correlation of lineations M20 to M25, as well as lineations M26, M27, and M28 within the Site 462 survey area (see Wipperman et al., this volume). Each of these lineations is composed of several magnetic reversals (Larson and Hilde, 1975), all of which are evident on Figure 1. It is primarily this continuity of detailed anomaly character that establishes the Late Jurassic age of the northern Nauru Basin in a regional sense.

On the basis of these studies, we planned Site 462 to penetrate oceanic crust in the Late Jurassic magnetic quiet zone-crust which would be somewhat older than

\footnotetext{
I Initial Reports of Deep Sea Drilling Project, Volume 61

2 Hawaii Institute of Geophysics Contribution No. 1121.
}

that at magnetic lineation M25. Although the explanation of this quiet zone is not obvious, its existence is well known in relation to five independent Late Jurassic plate boundaries in two separate oceans (Heirtzler and Hayes, 1967; Vogt et al., 1970; Vogt et al., 1971; Larson and Pitman, 1972; Hayes and Rabinowitz, 1975; Larson and Hilde, 1975; Larson, 1976). It subsequently was studied in the Nauru Basin in detail by Wipperman et al. (this volume), and across three independent plate boundaries in the western Pacific by Cande et al. (1978). Figure 2 shows cross-strike magnetic anomaly profiles in the vicinity of Site 462 , made by Wipperman et al. (this volume), and Figure 1 shows the geographic extent of this survey. This detailed survey shows low-amplitude ( 80 gammas) but very persistent magnetic-anomaly lineations across the Site 462 survey area, whose trend is essentially identical to the M20 to M25 sequence farther south (Fig. 1). Also shown on Figure 2 is a magneticanomaly block model and model profile, for anomalies M26, M27, M28, developed by Cande et al. (1978).

Cande et al. (1978) analyzed three independent lineation sequences in the western Pacific that were generated at three different plate boundaries; the Phoenix lineations generated at the Phoenix/Pacific plate boundary, the Japanese lineations generated at the Kula/ Pacific plate boundary, and the Hawaiian lineations generated at the Farallon/Pacific plate boundary. They demonstrated that fine-scale magnetic anomalies in each of these previously described "quiet zones" are lineated and can be correlated between lineation sequences (Fig. 3 ). Figure 3 shows a profile from each lineation sequence, the Phoenix profile V3214 passing directly across the Site 462 survey area (Fig. 1). These three profiles illustrate not only the detailed correlations of anomalies M22 to M25 previously described for the northern Nauru Basin (compare Fig. 1 to Fig. 3), but also the tapering amplitude envelope and magnetic anomalies M26, M27, M28, and M29 that characterize all of these lineation patterns. Site 462 is between anomalies M26 and M27 (Figs. 2 and 3), which should have a Late Jurassic (Oxfordian) age (Fig. 4). Figure 4 is the magnetic-reversal and relative-magnetic-intensity sequence deduced for the Late Jurassic by Cande et al. (1978). It shows that the tapering amplitude envelope results from a factor-of-four relative change in magnetic intensity that occurred gradually during the Late Jurassic, and it models anomalies M26, M27, and M28 as three short, reversely magnetized intervals, M27 being placed at the Oxfordian/Callovian boundary. This 


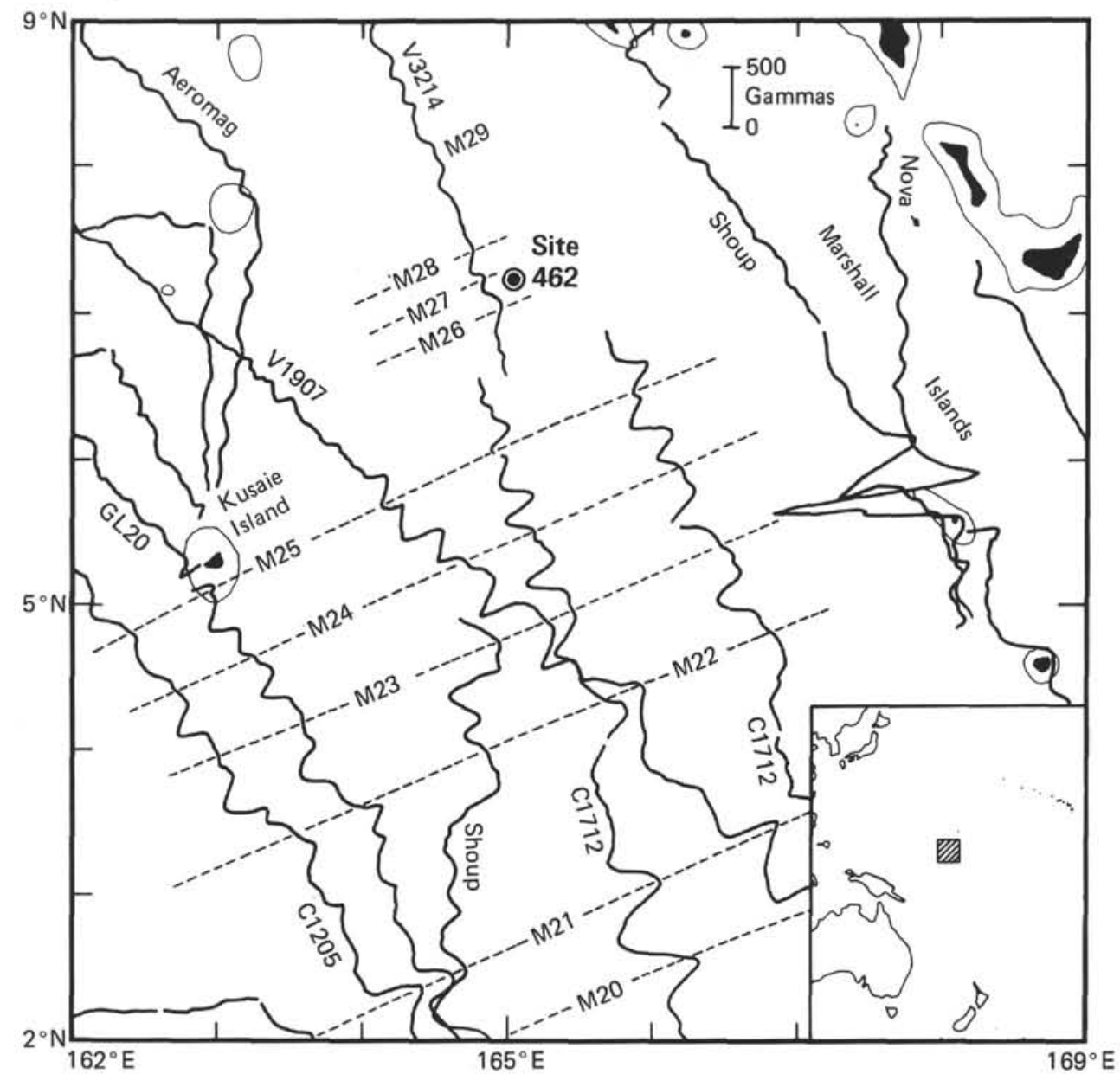

Figure 1. Magnetic-anomaly profiles in the northern Nauru Basin, showing magnetic lineations M20 to M29 (after Larson, 1976, and Cande et al., 1976). Box enclosing Site 462 locates area of Figure 2.

biostratigraphic calibration of M27 results from a relatively minor extrapolation of the Larson and Hilde (1975) time scale, which shows at least two DSDP calibration sites (100 and 105$)$ located relative to the reversal pattern within the Oxfordian. The absolute (radiometric) calibration of these time scales is much less certain. Cande et al. (1978) followed Larson and Hilde (1975) and used the Howarth (1964) time scale, which would date basement at Site 462 at 155 m.y. Subsequent studies of the Jurassic dating results by van Hinte (1976a) suggests that the absolute age of Site 462 is somewhat younger (148 m.y.), although the biostratigraphic location of Site 462 at the Oxfordian/ Callovian boundary in unchanged. We have adopted the date of 148 m.y. for use in this volume as the absolute age of the oceanic crust, but we use it in the nominal sense for uniformity, without the implication of precision better than $10 \mathrm{~m} . \mathrm{y}$.

We believe that this information demonstrates in some detail the identification of magnetic anomalies in the northern Nauru Basin near Site 462. This identification, the subsequent correlation to anomalies across other, independent lineation sequences, and the calibration of these magnetic reversals to a biostratigraphic time scale place the basement age of Site 462 at the
Callovian/Oxfordian boundary in the Late Jurassic. Regardless of the absolute (radiometric) age of this boundary, it appears that the drilling results of Site 462 must be interpreted in the context of a Late Jurassic basement whose magnetic signature has not been erased by subsequent Cretaceous volcanism.

\section{Stratigraphic Section}

Hole $462 \mathrm{~A}$ of Site 462 is located in the northern Nauru Basin, in 5177 meters of water, at $07^{\circ} 14.50^{\prime} \mathrm{N}$, $165^{\circ} 01.90^{\prime} \mathrm{E}$. A single-channel seismic-reflection profile made with a large-volume air gun essentially across the site location by R/V Kana Keoki is shown in Figure 5. The locations of Holes 462 and $462 \mathrm{~A}$ are shown on this profile, and the generalized ages, lithology, and sound velocity are plotted as functions of reflection time and sub-bottom depth. A more-detailed plot of this information is shown with the core locations on Figure 6. Figure 7 shows down-hole logging information obtained in Holes $462 \mathrm{~A}$ and 462 .

The reflection profile shown in Figure 5 is typical of the survey area, except for the clearer definition of the lowest reflectors, which was the deciding factor in drilling at this location. The upper 390 meters $(0.46 \mathrm{sec})$ is a relatively transparent section characterized by high- 


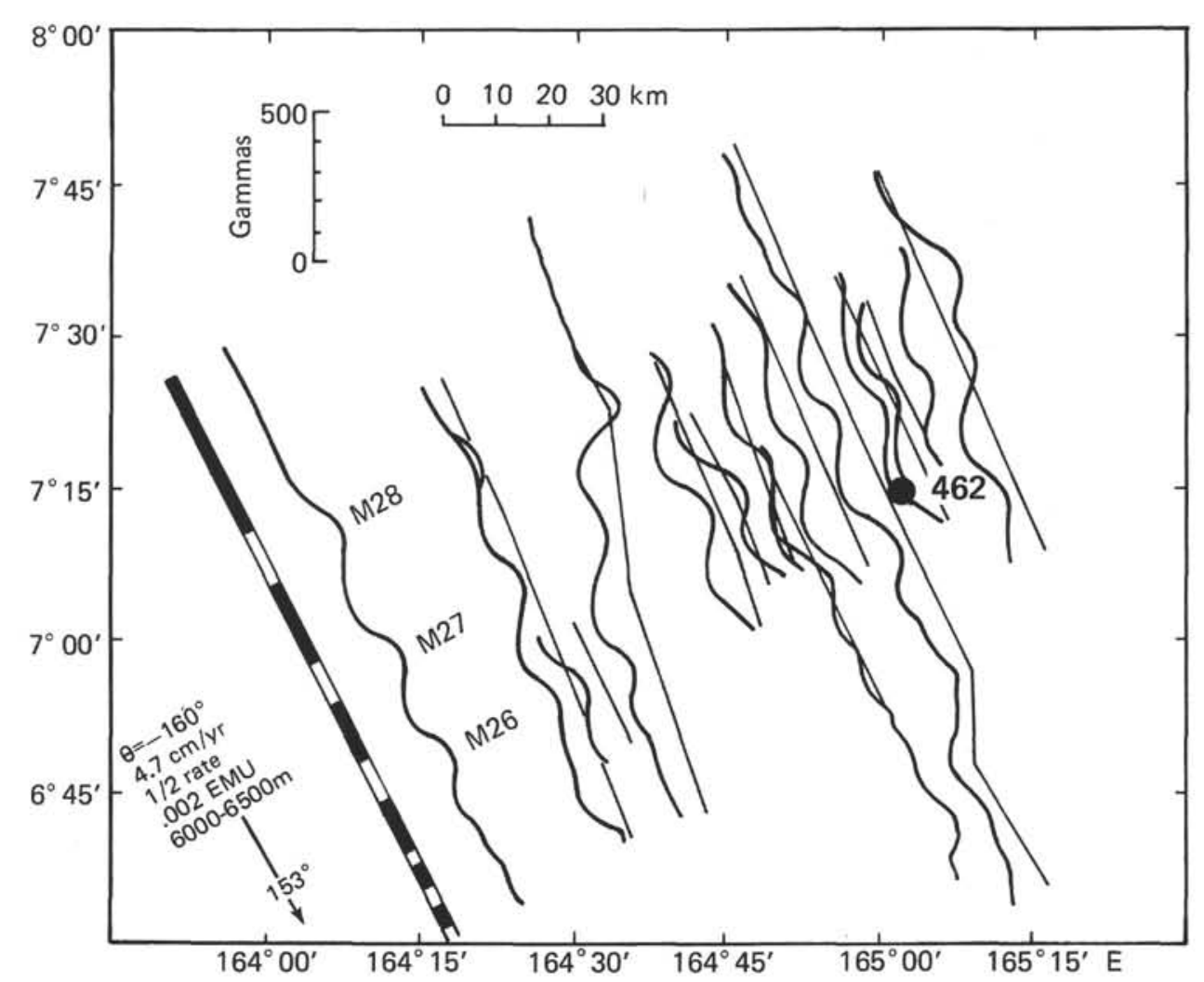

Figure 2. Cross-strike magnetic-anomaly profiles from the detailed geophysical survey of Site 462 by Wipperman et al. (this volume). Magnetic-reversal block model parameters shown on diagram with reversal boundaries based on the Late Jurassic time scale of Cande et al. (1978).
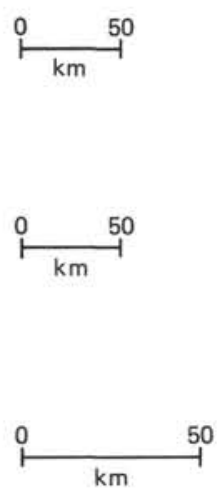

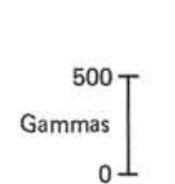<smiles>CCCCCCCCCCC</smiles>

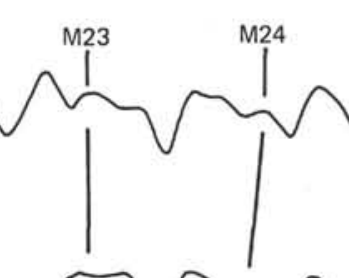

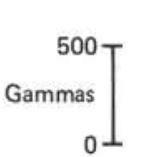<smiles>[CH]C</smiles><smiles>CCCCCCCCC</smiles><smiles>CCCCCCCCCCCCCCCC</smiles><smiles>CCCCCCCCC</smiles><smiles>[Mg][Mg]</smiles> 


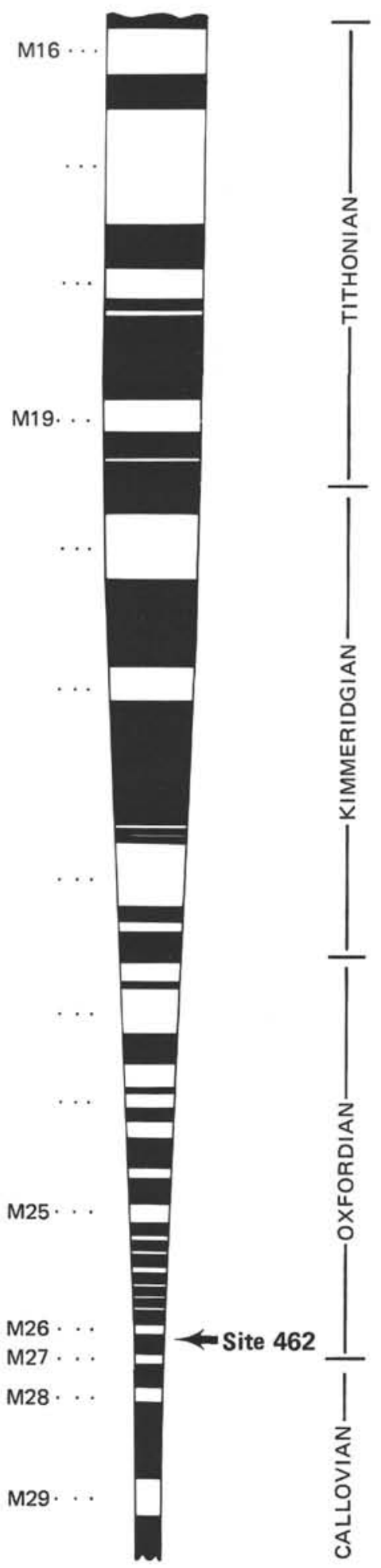

Figure 4. Late Jurassic magnetic-reversal time scale and relative magnetic intensity from Cande et al. (1978, fig. 6), showing Site 462 at the Oxfordian/Callovian boundary.

lie conformably below this level and may be multiples of the initial low-frequency arrival, or interval multiples within the chert sequence. This part of the section and transparent material just below it consists of Cretaceous (Maestrichtian to Cenomanian) claystones, siltstones, limestones, and volcaniclastic sediments. The latter are graded, scoured, and deformed siltstones, breccias, and reef debris, presumably largely products of basinal and edifice-building volcanism in the Cretaceous.

At 560 meters $(0.62 \mathrm{sec})$, a second set of somewhat more-discontinuous low frequency reflectors marks the top of the Cretaceous volcanic complex. The average impedance contrast responsible for this reflection surface is relatively large, with $1.94-\mathrm{km} / \mathrm{s}$. Cretaceous sediments overlying the $4.76 \mathrm{~km} / \mathrm{s}$ (average) upper basalt and volcaniclastic material. The upper section represented by these arrivals $(560-729 \mathrm{~m})$ is discontinuous, probably as a result of significant layers of volcanogenic sediments interbedded with the sills of the upper part of the volcanic complex. Below 729 meters, the low-frequency arrivals are much more continuous, indicative of the nearly solid sequence of layered flows.

\section{IGNEOUS ROCKS OF THE VOLCANIC COMPLEX}

Hole $462 \mathrm{~A}$ penetrated 504 meters of a Cretaceous volcanic complex composed mostly of igneous rocks, with interlayered sediments in the upper part. The basalt recovery from the pilot hole totaled 34 meters, and 287 meters of basalt was recovered from the multiple reentry hole.

Much of the following description of the stratigraphy, lithology, petrography, alteration, and chemistry of these igneous rocks is taken from Batiza et al. (this volume).

\section{Stratigraphy}

The Nauru Basin volcanic complex as revealed by drilling consists of two major units. The upper unit (cores 14 to 42 in Hole $462 \mathrm{~A}$ and cores 60-69 in Hole 462) consists of basalt sills with intercalated volcanogenic sediments. The sills vary greatly in thickness from less than 1 meter to over 50 meters, but all are basaltic. These sills intrude sediments which range in age from Cenomanian(?) to Barremian, based on the included fossils. This age range is consistent with an ${ }^{40} \mathrm{Ar} /{ }^{39} \mathrm{Ar}$ age determination of $110 \pm 3 \mathrm{~m} . \mathrm{y}$. on a sample from the upper sill complex (Ozima et al., this volume).

The lower unit of the igneous complex (Cores 44-92) consists of basalt flows of variable thickness and is separated from the upper sill unit by about 10 meters of Aptian-Barremian sediment. An ${ }^{40} \mathrm{Ar} /{ }^{39} \mathrm{Ar}$ age determination for a basalt sample from the lower unit gave a very poor isochron, and a total fusion age of $131 \mathrm{~m}$.y., which is difficult to interpret (Ozima et al., this volume).

\section{Lithology}

The sills of the the upper unit have altered glassy margins, and the grain size of the basalt increases toward the centers of the sills. They show clear contactmetamorphic effects in the intruded sediments (see Shcheka, this volume; Moberly and Jenkyns, this volume). One very thick sill contains late-magmatic granophyric patches consisting of intergrown quartz and potassium feldspar with two kinds of amphibole. Most of the sills contain veins and patches of secondary minerals and are altered to various degrees. Each sill appears to 


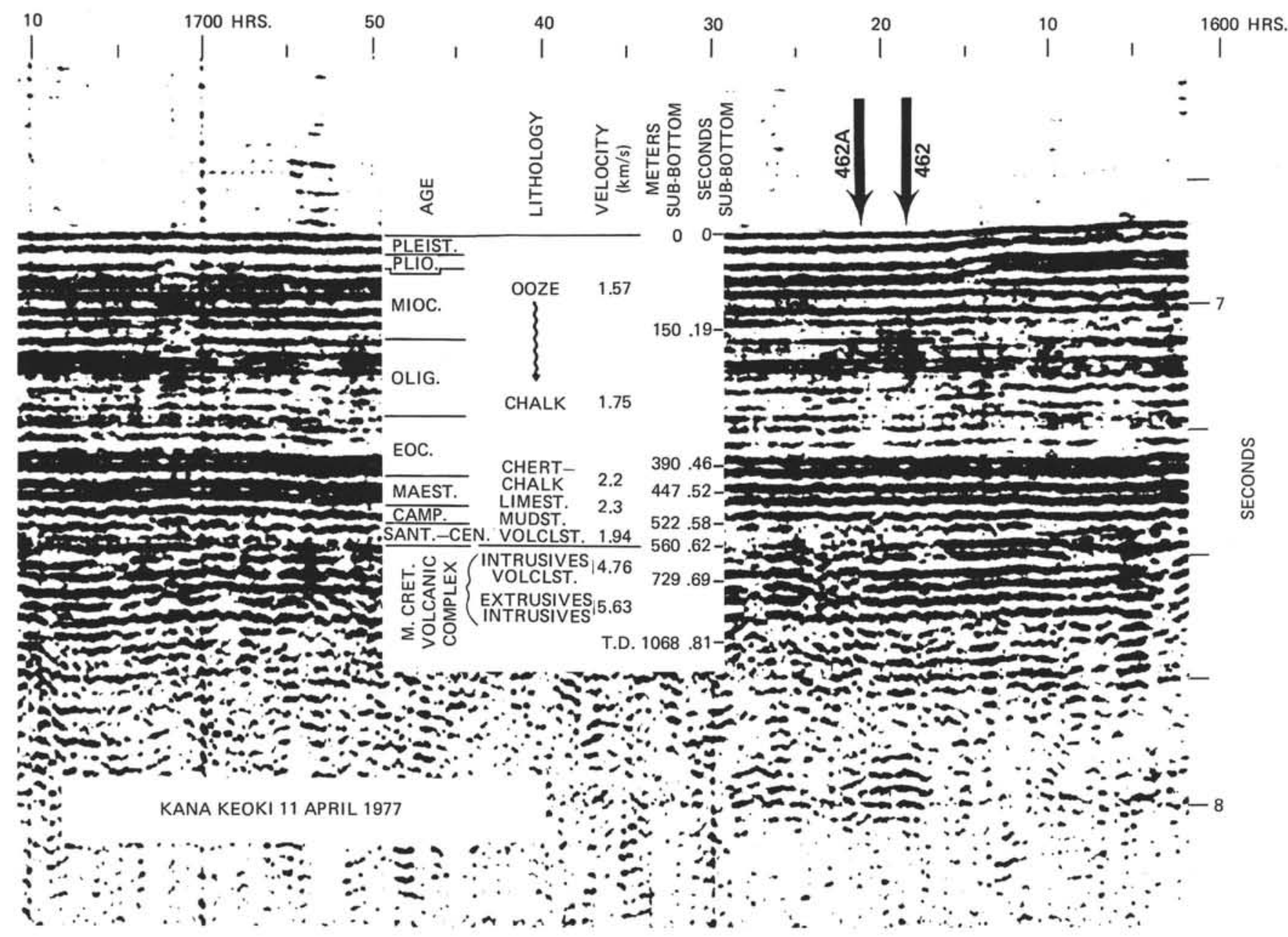

Figure 5. Seismic-reflection profile made across Site 462 by R/V Kana Keoki, with drilling results, showing generalized ages, lithology, and sonic velocities as functions of time and depth on the reflection profile.

be a single intrusion, with little evidence for multiple intrusions. (See Tokuyama and Batiza, this volume, for further discussion.) The uncommon grain-size inversions in the sills may be a result of multiple intrusion, but they also can be attributed to local mass movements within a single cooling unit, or to complex isotherm distribution with cooling sills.

The flows of the lower unit consist of upper glassy parts and thick, mostly holocrystalline lower parts. The glassy tops consist of multiple, thin, tabular, and contorted units, each consisting of upper and lower glassy margins up to $5 \mathrm{~cm}$ thick, separated by fine-grained, more-crystalline basalt. These grade downward into crystalline basalt units up to 30 or 40 meters thick. The thickness of the glassy portion of the units is commonly a few centimeters, but several thick sequences (up to 30 $\mathrm{m})$ of glassy material (with poor recovery) were penetrated.

These units are interpreted as basalt sheet flows similar to those described by Ballard et al. (1979). The glassy portions are thought to represent flow lobes on the top surface of a rapidly moving flow, and the great local thickness of packets of thin glassy units may indicate proximity to a vent. The thicker, non-glassy portions probably represent the more-massive flow interiors. Fresh glass is preserved in some of these units, but in general the basalt is veined and replaced by secondary minerals. No unambiguous pillow lava was cored in the igneous complex.

\section{Petrography}

The holocrystalline basalts all contain plagioclase, augite, $\mathrm{Fe}-\mathrm{Ti}$ oxides, and secondary minerals. Many contain pseudomorphs of euhedral olivine with small inclusions of spinel, but some of the flows have fresh olivine and spinel within fresh glass. Textures in the basalt vary widely, which probably reflects crystallization and cooling at various cooling rates and degrees of undercooling. They range from glassy to variolitic to hyalopilitic and holocrystalline. Most holocrystalline basalts are patchy and contain angular, fine-grained or glassy domains.

All the basalts are either aphyric or only sparsely phyric, with less than $10 \%$ (generally less than $3 \%$ ) phenocrysts. The observed crystallization sequences of the basalts are discussed by Tokuyama and Batiza (this volume). Plagioclase or spinel and olivine appear to be the liquidus phases of Leg 61 basalts and are followed 


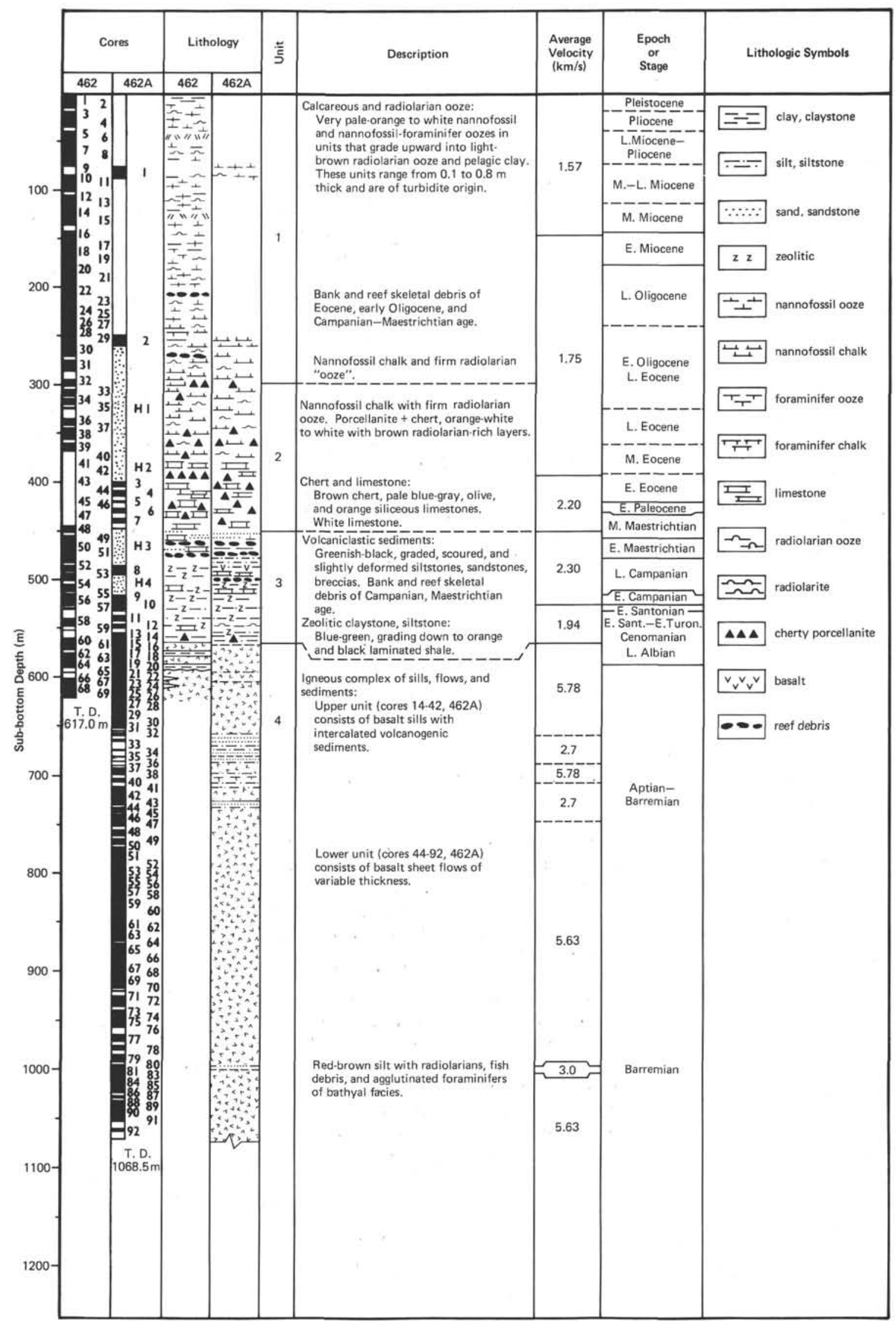

Figure 6. Columnar sections at Site 462 showing cored intervals, lithologic units, seismic interval velocities, and ages. 

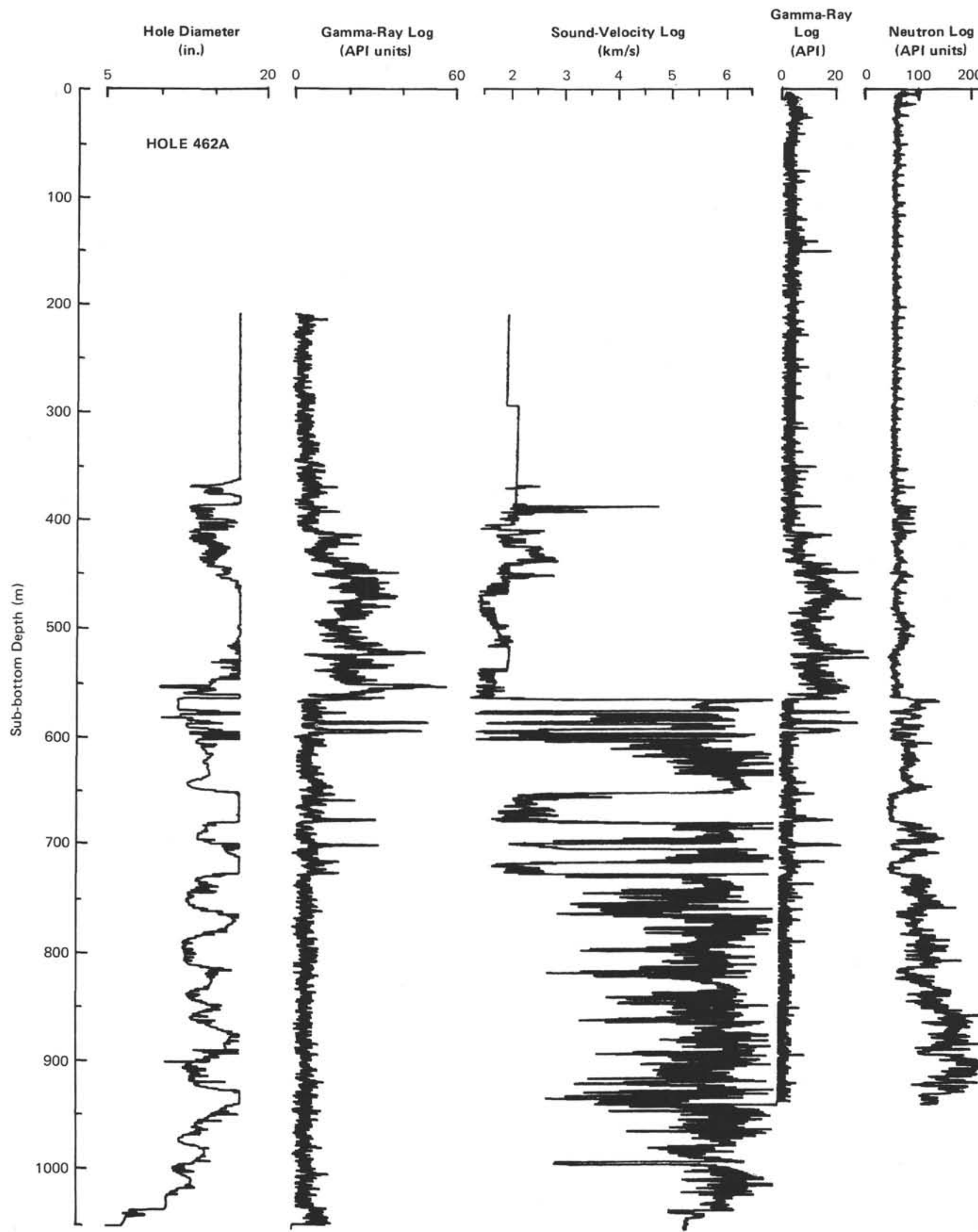

60

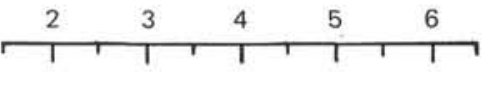

$\begin{array}{lllll}0 & 20 & 0 & 100 & 200\end{array}$
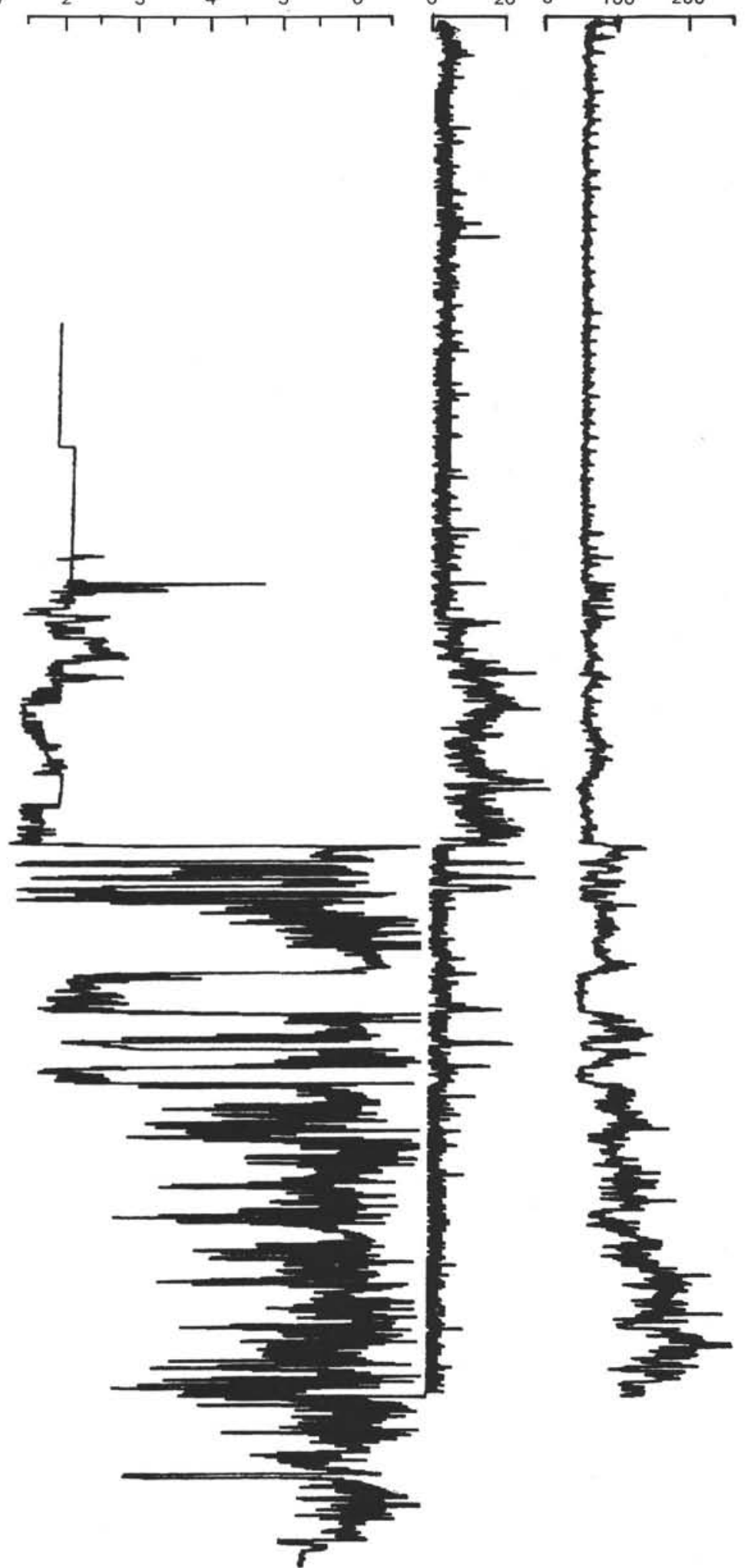

Figure 7. Results of logging at Site 462. 


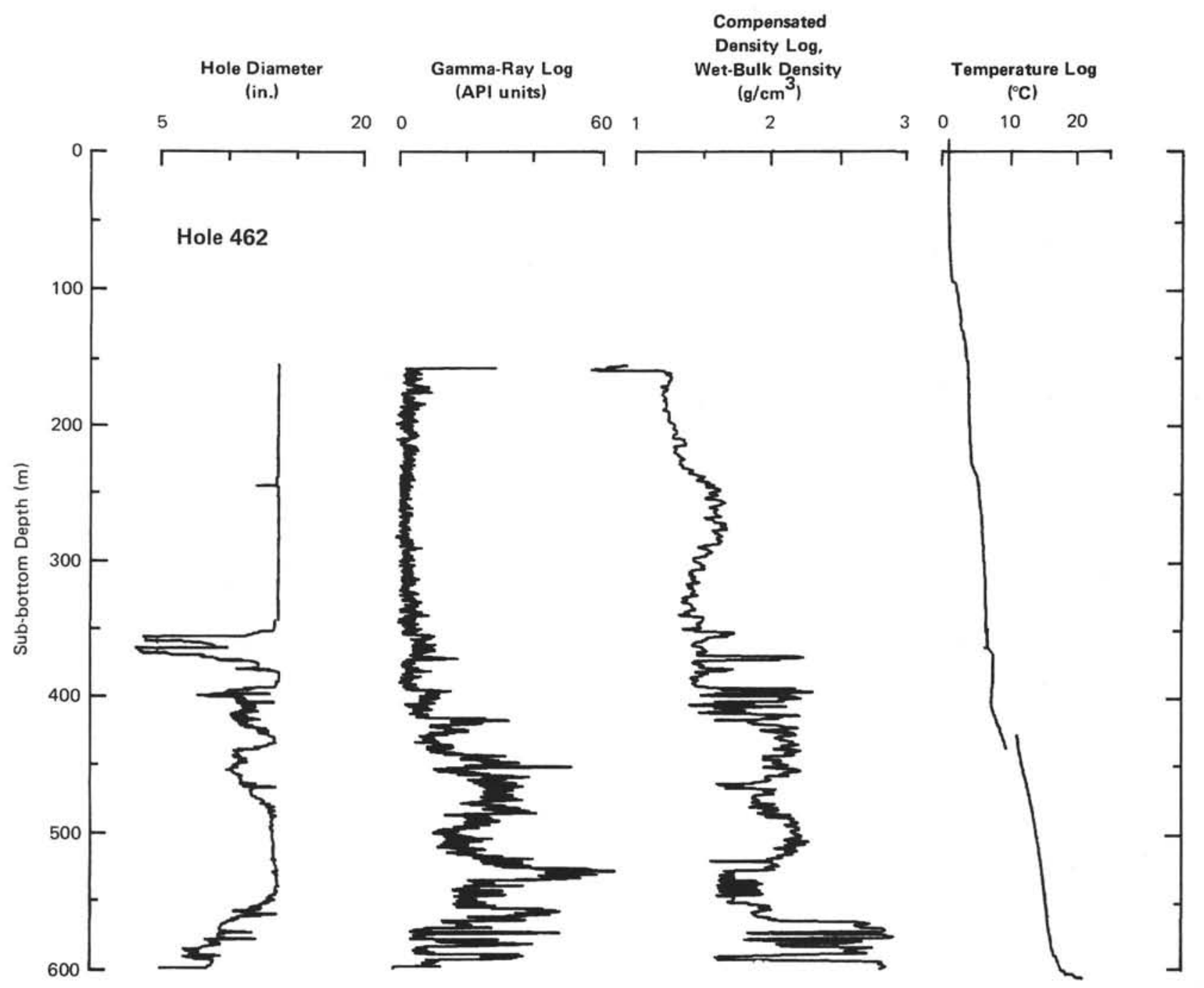

Figure 7. (Continued).

quickly by pyroxene. In rare cases, pyroxene appears to be the liquidus phase.

\section{Alteration}

Windom and Book (this volume) studied vein material in Leg 61 basalts; this study, together with petrographic observations and oxygen-isotope data, gives an integrated picture of the alteration history of Leg 61 basalts. By stratigraphic criteria, the oldest alteration event is that affecting the lower sections of flows. It is characterized by stabilization of zeolite, smectite, pyrite, calcite, and minor quartz, talc(?), and apophyllite; this event probably is similar to the non-oxidative alteration of normal mid-ocean-ridge (MORB) basalt by hydrothermal circulation which occurs shortly after eruption near mid-ocean ridges.

After rapid eruption of the flows and a period of sedimentation, sills were intruded into the overlying sedimentary section. The sills probably were altered by less-oxidizing sedimentary pore fluids of high $P_{\mathrm{CO}_{2}}$ by a process similar to that described by Einsele et al. (1979). Alteration minerals include smectite, calcite, pyrite, and quartz, a suite of secondary minerals common in MORB.

Superimposed on previous episodes of alteration is an oxidative alteration episode that resulted in stabilization of celadonite and Fe-oxides, and destruction of other smectites and pyrite. These effects are mainly restricted to the upper parts of the complex and provide evidence for rapid accumulation of the Nauru Basin igneous complex.

The $\delta^{18} \mathrm{O}$ values of 31 whole-rock powders which also were used in some of the other studies range from 5.8 to $10.2 \%$ SMOW. The observed variation is similar to that found at previously described DSDP sites, but the average $\delta^{18} \mathrm{O}(\sim 7.2 \%)$ is less than that found in the earlierdrilled holes (Muehlenbachs, 1980). No systematic difference in $\delta^{18} \mathrm{O}$ between the top sills and bottom flows is observed; $\delta^{18} \mathrm{O}$ versus $\mathrm{H}_{2} \mathrm{O}^{+}$systematics of four samples are similar to those of dredged and drilled basalts (Muehlenbachs and Clayton, 1972; Muehlenbachs, 1980 ), implying that the $\delta^{18} \mathrm{O}$ variation of the $462 \mathrm{~A}$ samples is caused by low-temperature alteration. The unaltered basalt has a $\delta^{18} \mathrm{O}$ of $5.8 \%$, identical to that of 
fresh MORB, but most samples are higher in $\delta^{18} \mathrm{O}$ (because of about $5 \%$ alteration, a few being up to $20 \%$ altered). These most-altered basalts $\left(\delta^{18} \mathrm{O} \simeq 10 \%\right.$ ) were sampled near flow or sill margins, zones of high transmissivity of sea water. There is no obvious explanation of why the $462 \mathrm{~A}$ samples are less altered (lower $\delta^{18} \mathrm{O}$ ) than the 110-m.y.-old 417A basalts (Muehlenbachs, 1980), as well as other Cretaceous basalts.

\section{Whole-Rock Chemical Analyses, Major Elements}

Shipboard analyses for $\mathrm{Si}, \mathrm{Al}, \mathrm{Ti}$, total $\mathrm{Fe}, \mathrm{Mn}, \mathrm{Mg}$, $\mathrm{Ca}, \mathrm{K}$, and $\mathrm{P}$ were completed for 33 samples, and for those elements other than $\mathrm{Mn}$ and $\mathrm{P}$ for another 113 samples of Leg 61 basalt. Additional wet-chemical analyses (42 total) and electron-microprobe glass analyses are given in Tokuyama and Batiza (this volume) and Shcheka (this volume). Analyses for $\mathrm{Al}, \mathrm{Ca}, \mathrm{Fe}, \mathrm{K}, \mathrm{Mg}$, $\mathrm{Mn}, \mathrm{Na}, \mathrm{P}$, and $\mathrm{Ti}$ in 15 additional samples are given by Fujii et al., (this volume), and major-element analyses of 14 other samples are given by Seifert (this volume). The great similarity of results obtained by various methods in different laboratories indicates that no serious interlaboratory biases exist.

The sills are systematically more fractionated than the lower flow units. Sills have consistently higher abundances of $\mathrm{Ti}, \mathrm{Fe}$, and $\mathrm{K}$, and lower abundances of $\mathrm{Mg}$ and $\mathrm{Ca}$ than flows, with essentially no overlap in compositional range. It is very unlikely that these chemical differences are caused by oxidative alteration, because this alteration does not greatly affect rocks below Core 19 in Hole $462 \mathrm{~A}$. Furthermore, $\mathrm{Fe}^{+3} / \mathrm{Fe}_{\text {tot }}$ ratios of both sills and flows are relatively low: 0.29 is the mean for the sills, and about 0.36 for the flows, albeit with much scatter. Oxygen-isotope data and petrographic observations also indicate that all the rocks are only slightly altered, and that large systematic differences in the degree of alteration do not exist. Thus, the systematic variation in chemical composition between the sills and the flows is probably a reflection of differences in igneous petrogenetic processes between the two rock types.

Both sills and flows are chemically similar, but not identical to suites of MORB. Nauru Basin basalts are either quartz or olivine-hypersthene normative. The trends of chemical variation exhibited by the Nauru Basin suite are, however, different in detail from trends observed in fractionated suites of MORB. For example, at comparable $\mathrm{Mg} /\left(\mathrm{Mg}+\mathrm{Fe}^{+2}\right)$ ratios, the Nauru Basin basalts have systematically less $\mathrm{TiO}_{2}$ than suites of MORB (Shcheka, this volume; Tokuyama and Batiza, this volume; Batiza et al., 1980).

Systematic variation of chemical composition with stratigraphic position is observed within the Nauru Basin (Shcheka, this volume; Batiza, this volume). In the upper sill unit, the degree of $\mathrm{Ti}$ and $\mathrm{Fe}$ enrichment generally correlates with stratigraphic position: $\mathrm{Ti}-$ and Fe-rich rocks are stratigraphically higher in the section, although there is some scatter. In contrast, the flow section shows the opposite relationship: flows higher in the section are systematically more depleted in $\mathrm{Fe}$ and $\mathrm{Ti}$ than those near the base. There is essentially no com- positional overlap between the flow section and the sill section, although they are chemically similar.

This variation is reflected in a systematically higher $\mathrm{Mg} /\left(\mathrm{Mg}+\mathrm{Fe}^{+2}\right)$ ratio for flows than for sills. Most of the flows have an $\mathrm{Mg} /\left(\mathrm{Mg}+\mathrm{Fe}^{+2}\right)$ ratio greater than 0.60 , and many are about 0.64 to 0.65 , indicating that they may be primary mantle melts which have undergone relatively little fractionation.

\section{Trace Elements}

Batiza (this volume) and Seifert (this volume) give instrumental neutron-activation analysis (INAA) determinations of seven rare-earth elements (REE: La, Ce, $\mathrm{Sm}, \mathrm{Eu}, \mathrm{Tb}, \mathrm{Yb}$, and $\mathrm{Lu}$ ), in addition to $\mathrm{FeO}, \mathrm{Sc}, \mathrm{Cr}$, $\mathrm{Co}, \mathrm{Ni}, \mathrm{Na}_{2} \mathrm{O}, \mathrm{Hf}$, and Th, for 52 samples of Leg 61 basalt. Shcheka (this volume) gives analyses for $\mathrm{Zr}, \mathrm{Rb}$, and $\mathrm{Sr}$ by XRF methods; $\mathrm{Cr}, \mathrm{Ni}, \mathrm{Co}$, and $\mathrm{Zn}$ by atomicabsorption methods; and V and Sn by spectroscopic methods, for 30 samples. Fujii et al. (this volume) present analyses for $\mathrm{Ba}, \mathrm{Li}, \mathrm{Sc}, \mathrm{Sr}, \mathrm{V}$, and $\mathrm{Y}$ by opticalemission spectrometric methods for 17 samples, and $\mathrm{Sr}$ and $\mathrm{Rb}$ analyses by isotope dilution for three samples. Tokuyama and Batiza (this volume) present additional $\mathrm{Ni}, \mathrm{Co}, \mathrm{Cr}$, and $\mathrm{S}$ atomic-absorption analyses for seven samples. Considering the analytical precision and accuracy of the various methods used, these results are in excellent agreement.

Trace-element data agree with major-element data in the following ways: (1) the basalts of the Nauru Basin igneous complex are similar, but not identical to MORB, (2) the sills are more fractionated than the flows, (3) systematic stratigraphic compositional trends exist within both the sills and flows, and (4) the chemical effects of alteration are minimal. Observed trace-element variations reflect primary igneous processes, not the chemical effects of alteration. Some observed scatter in the chemical variation of some major and trace elements may, however, be due to the effects of alteration.

Both sills and flows show depletion of the light REE relative to the heavy REE, as do MORB samples. The flows have $\mathrm{K} / \mathrm{Rb}=1050-1100, \mathrm{~K} / \mathrm{Ba}>50, \mathrm{Rb}<1$ $\mathrm{ppm}, \mathrm{Sr} \simeq 100 \mathrm{ppm}, \mathrm{Zr} \simeq 80 \mathrm{ppm}$, and other traceelement similarities to MORB. The sills have slightly higher levels of incompatible trace elements, but ratios of these elements are similar to ratios observed in the flows. This is consistent with greater fractionation of the sills.

\section{Paleomagnéism}

Steiner (this volume) measured the paleomagnetic properties of the Late Cretaceous sediments overlying the Cretaceous volcanic complex, to determine the reversal stratigraphy of these sediments and the Late Cretaceous paleolatitude of the site. She measured Campanian to Cenomanian sediments, focusing particular interest on the Campanian material. The magnetization of these sediments is very stable, alternatingfield demagnetization having only minor effects on sample directions. Median destructive fields were greater than $150 \mathrm{Oe}$, and generally greater than $200 \mathrm{Oe}$. Samples also were thermally demagnetized in $50^{\circ} \mathrm{C}$ steps up 
to $675^{\circ} \mathrm{C}$, and neither of these demagnetization techniques significantly affected magnetization directions.

The Late Cretaceous sections of the two holes are remarkably similar. Both show a 10-meter-thick reversed interval in early Campanian sediments, with an apparent short-normal excursion near the top of the reversed interval. This is the only reversed interval in the entire section, interpreted to be the interval bounded by Anomalies 33 and 34 in magnetic-anomaly profiles, located within Campanian strata at the same stratigraphic level in the Gubbio, Italy, type section. Demagnetized samples suggest an early Campanian paleolatitude of $8.4 \pm 3.7^{\circ} \mathrm{S}$. On the average, these results are in accord with results from material of similar age from the adjacent Ontong-Java Plateau, although it is surprising that there is no obvious change in the Nauru Basin's paleolatitude over the $\sim 20 \mathrm{~m} . \mathrm{y}$. from Cenomanian to Campanian time.

Steiner (this volume) measured the paleomagnetic properties of the Cretaceous volcanic complex in both Holes 462 and $462 \mathrm{~A}$. Her study focused on the remanent magnetic properties of the basalts, in order to determine the paleolatitude of the igneous complex and to gain additional evidence on its history of implacement.

Except for one sediment sample, all samples of basalt and intercalated sediments display upward-directed NRM inclinations corresponding to normal polarity at the site's presumed southern paleolatitude. There is a strong correlation of increasing grain size and increasing negative inclination, which suggests that a strong negative overprint has been imparted to these samples by drilling. The lowest 130 meters in Hole $462 \mathrm{~A}$ is composed of coarse-grained diabase with inclinations of $-70^{\circ}$ to $-85^{\circ}$; the rock appears to be completely remagnetized.

Demagnetization of the fine-grained basalts does not markedly alter their NRM inclinations. Median destructive fields are 80 to $120 \mathrm{Oe}, 30$ to $70 \%$ of the NRM intensity remaining when a stable field direction is reached. In contrast, the coarser-grained basalts have MDFs of 20 to $60 \mathrm{Oe}$ and require removal of 80 to $90 \%$ of their NRM intensity before "stability" is reached. Although many of these rocks are only "softly" magnetized, there is no evidence that secondary alteration has affected the magnetization of these samples.

Realizing that these are not ideal igneous samples for remanent-magnetization studies, the following conclusions still can be reached. Two groups of inclinations exist: $-51.8 \pm 7.2^{\circ}$ for the upper intrusive sequence, and $-31.8 \pm 6.6^{\circ}$ for the lower extrusives. The lowest 130 meters of the hole has been remagnetized, and yielded no useful paleomagnetic information. The inclination of the intrusives corresponds to a normally magnetized paleolatitude of $32^{\circ} \mathrm{S}$ (ranging between $26^{\circ}$ and $40^{\circ} \mathrm{S}$ ), and that of the extrusives to $21^{\circ} \mathrm{S}$ (ranging between $17^{\circ}$ and $26^{\circ} \mathrm{S}$ ). At least part of this igneous complex is likely to be of Early Cretaceous age, because the extrusive basalts enclose Barremian sediments, and one basalt sample is reliably dated at $110 \pm 3 \mathrm{~m} . \mathrm{y}$. Larson and Chase (1972) and Lancelot and Larson (1975) suggest an Early
Cretaceous paleolatitude of $20^{\circ}$ to $30^{\circ} \mathrm{S}$ for this site, and Aptian basalts from the Ontong-Java Plateau predict a Site 462 paleolatitude of $24^{\circ} \mathrm{S}$ at that time (Hammond et al., 1975). Thus, both the intrusive and extrusive rocks have inclinations close to the predicted paleolatitude and probably contain significant paleolatitude information. Furthermore, the extrusive and intrusive sequences and the overlying Late Cretaceous sediments all have significantly different paleolatitudes, connoting significantly different ages. However, it cannot be argued that a secular variation has been averaged out by either the extrusives or intrusives; it probably has not. Thus, it is likely that the igneous complex was emplaced in two short magnetic episodes that recorded not only paleolatitudes, but also secular variation. The magnitude of the two inclinations favors emplacement of both the extrusive and intrusive rocks in Early Cretaceous time.

\section{Radiometric Dating}

Ozima et al. (this volume) applied the ${ }^{40} \mathrm{Ar}-{ }^{39} \mathrm{Ar}$ stepheating technique to three igneous samples from Holes 462 and $462 \mathrm{~A}$. These samples were selected for their abnormally high potassium contents, ranging from 0.44 to $0.78 \%$, compared to most samples from these holes, whose $\mathrm{K}$ content is about $0.1 \%$. These values are still minimal for argon dating, and their relatively elevated values might suggest $\mathrm{K}$ introduction during alteration. However, one date (Ozima et al., this volume) was achieved from these samples and microscopic examination did not yield any positive evidence of $\mathrm{K}$ introduction during alteration.

Sample 462A-32-1, 46-49 cm is a clinopyroxene-plagioclase phyric basalt from the upper intrusive sill complex of Hole $462 \mathrm{~A}$ ( $655 \mathrm{~m}$ sub-bottom). The isochron plot is a very linear data set, except for the $600^{\circ} \mathrm{C}$ fraction, where only $1.6 \%$ of the total ${ }^{39} \mathrm{Ar}$ was released. It gives an age of $110 \pm 3 \mathrm{~m} . \mathrm{y}$. , in close accord with the total-fusion age of 103.7 m.y., suggesting a slight loss of radiogenic ${ }^{40} \mathrm{Ar}$ from the sample. The other two samples gave very ragged isochron plots and are not useful for dating, so that the only useful age appears to be the $110 \pm 3 \mathrm{~m}$.y. from the upper intrusive sill complex.

\section{CRETACEOUS SEDIMENTS}

The flows and sills described above are interlayered with and underlie sedimentary rocks of Cretaceous age. These sediments range from Barremian through middle Maestrichtian and are dominated by volcanogenic components. They are described in detail by Moberly and Jenkyns (this volume); much of this section is taken from their chapter.

\section{Hyaloclastite of Barremian Age}

The oldest fossils recovered from the Nauru Basin are in a radiolarian assemblage assigned to the Eucrytis tenuis Zone, from hyaloclastite in Section 80-1 of Hole $462 \mathrm{~A}$. The radiolarians are size-sorted and associated with fish debris and agglutinated foraminifers in laminae. Much of the recovered core is without sedimentary structure, but some horizontal and cross-laminae indi- 
cate bottom currents. This sediment was laid down at bathyal depths under the influence of bottom currents possibly set up by the volcanic activity that provided the fresh glassy basalt that fractured to form the hyaloclastite.

\section{Hyaloclastites of Middle Cretaceous Age}

The upper sills of the volcanic complex intrude hyaloclastites that grade upward into zeolitic mudstones. A late Aptian nannofossil assemblage in Core 40 of Hole $462 \mathrm{~A}$ is the only fossil age obtained between the Barremian sediment discussed above and the top of the sill complex which intrudes late Albian or Cenomanian sediments. The nannofossil assemblage is $99 \% \mathrm{Watz}$ nauria barnesae and may represent a dissolution facies. Deep-water agglutinated foraminifers are associated with radiolarians, fish debris, sponge spicules, and plant debris. These fossils suggest deposition in deep water, at or below the CCD. The plant remains indicate nearby islands during Aptian time (see Jenkyns and Schlanger, this volume). The composition of the organic-carbon compounds in the sediments indicates deposition in oxygenated water (Thomson and others, this volume). Most of the sediment was originally angular fragments of basaltic glass; this has been altered to smectite and analcime. Primary sedimentary structures include horizontal and cross-laminae, graded beds, and soft-sediment deformation. Below some sills, the hyaloclastites show metamorphic effects, such as growth of magnetite spheres, analcime, smectite, fine needles of actinolite, patches of pyrite, and radiating, fibrous aggregates of an unidentified zeolite. The hyaloclastite section above 700 meters has been altered by moderate-temperature reactions between circulating sea water and basalt (Moberly and Jenkyns, this volume).

\section{Varicolored Claystones and Related Sediments Above the Sills}

Deposits of Santonian and early Campanian age in Holes 462 and $462 \mathrm{~A}$ range from claystones to siltstones. Apart from local faint horizontal lamination and rare fucoid and Chondrites burrows, this argillaceous section is essentially structureless; rare intercalations of horizontally bedded greenish-gray volcaniclastics provide the only punctuation. Of note is the presence of thin strands of native copper (462A-9-5), surrounded by haloes of pale-bluish-green sediment. Fossils, which are locally common, include radiolarians, sponge spicules, sparse nannofossils, and fish remains. The radiolarians typically are recrystallized, but are better preserved in the greenish-blue than in the reddish-brown claystones. These claystones pass downward through brownishblack (and manganiferous) claystones that rest (with an intercalated black chert) on basalt of the highest sill.

The minerals are typical of pelagic clays, with varying amounts of clay minerals, zeolites, and feldspars, plus quartz, phosphate, and calcite. Apart from the three last-named substances, the minerals betray a clear igneous parentage. Most of the clay is present as a mixedlayer illite-montmorillonite, with some smectite; the latter mineral strongly suggests derivation from degraded igneous material, whereas the origin of the mixed-layer mineral is more equivocal; authigenic illite-montmorillonite clays derive either from diagenetic transformation of volcanic ash, or from continental soils. Furthermore, burial diagenesis can readily transform smectites to mixed-layer species, and much of the illite-montmorillonite may be a simple product of time and temperature (see Moberly and Jenkyns, this volume).

The chemistry of the claystones is unremarkable and shows patterns typical of halmyrolitic alteration of basalt. Trace elements show levels that do not depart significantly from those of ocean-floor basalts. The trace-element concentrations in the Nauru Basin claystones are distinctly lower than those of Recent Pacific pelagic clays, except for zinc.

When compared with Pacific spreading-ridge sediments, the multicolored claystones are markedly enriched in $\mathrm{SiO}_{2}, \mathrm{Al}_{2} \mathrm{O}_{3}$, and $\mathrm{TiO}_{2}$, and locally in $\mathrm{K}_{2} \mathrm{O}$, and are depleted in $\mathrm{P}_{2} \mathrm{O}_{5}$, and particularly in $\mathrm{MnO}$; trace metals are also lower in the claystones. Although the quantities of $\mathrm{Mn}$ are low, as the contact with basalt. is approached the colors change to shades of brown to black and the amounts of manganese rise (462A-12-1, $27-31 \mathrm{~cm} ; 13-2,138-142 \mathrm{~cm} ; 13-3,1-3 \mathrm{~cm}: \mathrm{MnO}=$ $0.23,1.56$, and $2.05 \%$, respectively; shipboard XRF data). Other elements ( $\mathrm{Cr}, \mathrm{Ni}, \mathrm{Co}, \mathrm{Sc}, \mathrm{Pb}$, and $\mathrm{Cu})$ also increase in abundance toward the contact (Kurnosov, this volume). The basalt/sediment contact is at $462 \mathrm{~A}$ $15-1,12 \mathrm{~cm}$.

It is clear that these Nauru Basin sediments show chemical features in common with, yet distinct from, Pacific pelagic clays and spreading-ridge deposits. The only element that is uniquely concentrated is titanium, and some explanation must be sought for this enrichment. The geochemical behavior of titanium, given that it is readily hydrolyzed, is largely governed by the immobility of the dioxide above a $p \mathrm{H}$ of 2.5 ; thus, the element is concentrated in virtually all subaerial weathering environments. High titanium contents in soils formed on basaltic and other substrates indicate intense weathering. Similarly, the enhanced $\mathrm{Ti}$ levels of the Nauru Basin claystones must be a token of submarine degradation of basalt. These sediments therefore represent a distinct class of basal deposits, distinct from those found on spreading ridges, and distinct from typical pelagic clays, to which they nonetheless contribute.

Sediments very similar to the Nauru Basin claystones were cored near the Line Islands during DSDP Leg 33. These deposits, colored in various shades of red and blue-green, are similarly titaniferous, and were attributed to submarine weathering of basalt. Clearly there is a general chemical similarity, although the samples from the Line Islands site are generally more richly endowed with $\mathrm{Fe}_{2} \mathrm{O}_{3}, \mathrm{MnO}$, and $\mathrm{MgO}$, and contain some levels particularly rich in $\mathrm{TiO}_{2}$. Traces of anatase were recorded from Hole $315 \mathrm{~A}$, something not identified from the Nauru Basin.

As mentioned above, as the basalt sills are approached down-hole, the content of manganese and other metals rises, suggesting post-depositional injection of these elements from weak hydrothermal solu- 
tions emanating from the hypabyssal sill complex. Similar geochemical trends are reported by Natland (1976) in his study of red claystones-apparently also produced by weathering of basalt-lying atop Meiji Guyot in the North Pacific. Persuasive, perhaps, of the reality of minor hydrothermal injection is the presence of native copper in the Nauru Basin claystones some 47 meters above the igneous/sedimentary contact; certainly the several occurrences of native copper in sediments of DSDP cores are conventionally attributed to this or a related mechanism (e.g., Hole 105, Lancelot et al., 1972; Hole 317A, Jenkyns, 1976; Hole 364, Siesser, 1978).

In conclusion, we suggest that the multicolored claystones of Holes 462 and $462 \mathrm{~A}$ are derived largely from in situ weathering of glassy-basalt fragments, and that titanium provides a geochemical fingerprint of this process. Given that Cretaceous intraplate volcanism now has been recognized as a phenomenon of regional significance across the Pacific, influencing the development of or creating the Line Islands, the Marshall Islands, the Mid-Pacific Mountains, other edifices, and the Central Basin (Watts et al., 1980; Schlanger and Premoli Silva, this volume), it follows that titaniferous sediments should also characterize this area.

Presumably, the intrusions of the sills into the hyaloclastite and weathered hyaloclastite took place because the igneous/sedimentary contact was a plane of weakness. The density of the deeply weathered and partly pelagic Cenomanian through Santonian clays probably was not greatly different than the density of water, yet denser than the more rapidly deposited Lower Cretaceous sandy hyaloclastite, and so some sills were emplaced at the base of the deeply weathered mantle. Other masses of magma almost certainly broke through to the sea floor, as discussed below.

\section{Volcaniclastic Sediment of Late Cretaceous Age}

Between about 450 and 490 meters is a series of greenish-black to gray sandstones, siltstones, and fine breccias of volcanic composition, displaying graded bedding, scours, and soft-sediment deformation. Planktonic fossils within them are of late Campanian and early Maestrichtian age. The texture, composition, structures, and probably volume of the volcaniclastic assemblage can be used to deduce its probable origin. The primary sedimentary structures and textures indicate that part of the material had a nearby source, whereas the composition indicates that part had traveled from the edge of the Nauru Basin. The volume suggests local sources.

A single 2.5 -meter graded bed in Core 51 is the thickest of several volcanic-rich beds discovered. Its top shows escape burrows, and its base has inclined bedding and lies on contorted mudstones having phacoidal structure. If the entire bed has much lateral extent, its volume must be immense. It seems probable (Moberly and Jenkyns, this volume) that most if not all of its source was a nearby slope that was gravitationally unstable. Slump folds suggest that the mass of sediment overlying the deformed part slipped en masse. These folds record gravitational instability. The sea floor close by was ele- vated or depressed fairly quickly relative to the DSDP site, perhaps a result of nearby volcanism or faulting. Scoured surfaces indicate strong local currents.

Load casts from cross-bedded volcanic sands deposited on burrowed calcareous ooze, now sandstone on limestone, are found in Sections 462-50-5 and 51-1. These, and the escape burrows in other cores, resulted from the sudden, episodic introduction of volcanic sand into this part of the Nauru Basin.

Small but important parts of these rocks are beds of redeposited shallow-water sands, reef limestones and fossils, phosphorite, and probable subaerial basalt. Redeposited fossils of shallow-water origin include the large benthic foraminifers Pseudorbitoides, Vaughanina, Lepidorbitoides, Asterorbis, Sulcoperculina, and Orbitocyclina. In addition, debris from rudistids, red algae, bryozoans, and echinoids is present (PremoliSilva and Brusa, this volume). These fossils record Late Cretaceous reefs in the northern Marshalls. Prior to Leg 61 , the oldest reefs found in the Marshalls were Eocene (Schlanger, 1963). These fossil-bearing volcaniclastic sediments are evidence of the growth and erosion of the volcanoes that today are the foundations of the Marshall Islands and associated guyots, as discussed elsewhere in this volume (Schlanger and Premoli Silva). Some beds are pelagic limestones.

A great part of the sand and silt is hyaloclastite, now smectite clay. The coarser sand grains of some beds are intraformational clasts of hyaloclastic siltstone, with a sparse matrix of fine hyaloclastite sand, cemented by calcite spar. Pebbles and sand of basalt glass altered to clay are at the bases of some graded beds. Even if they were not clay at the time of transportation, their size indicates that they did not travel far.

In the breccia bed of Section 462-51-1, the pebbles are mainly of volcanogenic siltstone, but they also include limestone and basalt fragments. This intraformational breccia almost certainly had a nearby source. Some beds contain angular hyaloclastite with planktonic foraminifers and nannofossils, along with reworked grains of probable shallow-water origin, suggesting mixing and sorting of three components. Thermally mature hydrocarbons are preserved as high as the lower Maestrichtian rock in Core 462-49 (Thomson et al., this volume). Hydrocarbons may be generated and migrate one or more times, and so the unanswered question remains, was there a Late Cretaceous episode of heating prior to the one that can be correlated with the late Santonian to early Maestrichtian volcaniclastic sediments?

In Section 462-50-3, the cross-beds between 136 and $141 \mathrm{~cm}$ are partially replaced by iron-rich brown clays in shapeless masses that surround veinlets of bright-green, moderately birefringent phyllosilicate, probably celadonite. Apparently, the bedding planes were conduits for hydrothermal solutions during (or after) the early Maestrichtian.

\section{Possible Volume}

Site 462 lies within the Nauru Basin, which covers an area of about $10^{6} \mathrm{~km}^{2}$. The upper seismic reflectors and level topography are more or less continuous across the 
basin. Extrapolation of a third dimension from the record of a single drill site is extremely risky, but there is perhaps a 10-meter thickness of volcanic addition to the basin within the Campanian and Maestrichtian strata. To an order of magnitude, there may have been about $10 \pm 5 \times 10^{4} \mathrm{~km}^{3}$ of lava that provided the sediment. Where might that volume have been obtained?

About 20 of the Marshall and Gilbert volcanic pedestals rim the north and east edges of the Nauru Basin. Each has a present volume of 1 to $8 \times 10^{4} \mathrm{~km}^{3}$, but it is impossible to measure the volume they could have contributed to the basin. If we assume that all former rock above the present regional guyot depth of about 1100 meters was eroded as volcanic sand and silt (none leached or weathered to clay), and all was delivered southwest into the Nauru Basin, that would have been about $4 \times 10^{3} \mathrm{~km}^{3}$. Submarine erosion of fragmented glass from the volcano slopes may have doubled or tripled this amount, but it remains small compared with the estimate of silt and sand in the basin.

These very rough calculations suggest that although far-traveled turbidites from the Marshall or Gilbert Islands are known to have contributed shallow-water detritus to the Nauru Basin, it seems unlikely that they were the sole source or the dominant source of the volcanic grains. Probably, multiple sources were available nearby, wherever the feeders of the hypabyssal basalt sills broke through to the sea floor (Moberly and Jenkyns, this volume).

\section{CENOZOIC SEDIMENTS}

At present, yellowish-brown and reddish-brown, radiolarian-bearing clays with manganese nodules are being deposited at Site 462 in the Nauru Basin, at a depth of 5190 meters. This lithology was already described from piston core MP-1 taken by R/V Kana Keoki during the pre-site survey. However, the section at the site, at least down to Core $462-39$, is dominated by calcareous, pelagic turbidites resedimented from shallower depths (Premoli Silva and Violanti, this volume).

One of the more recent sedimentological events of note is represented by volcanic ash of late Miocene (Core 462-6) and Pliocene age (Core 462-4; Site Summary, this volume). These are interpreted as a result of formation of volcanic edifices in the eastern Caroline Islands. In particular, the ash in Core $462-4$ is most prominent. It occurs in zones NN14 to NN15(?) and PL6(?), spanning ages of 2 to 4 m.y. This ash is taken to represent the formation of Kusaie Island, the easternmost and presumably youngest of the Caroline Islands. A recent $\mathrm{K}$-Ar date (3.4 m.y.) from a basalt from $\mathrm{Ku}$ saie (Barbara Keating, pers. comm., 1980) confirms this interpretation.

The pelagic turbidites that volumetrically dominate the Cenozoic section typically show up as discrete units 0.1 to 8 meters thick. These have a basal layer of white foraminifer-nannofossil ooze which grades up into light-brown radiolarian ooze, which in turn is capped by reddish-brown pelagic clay representing the "background" sedimentation. The bathymetry around Site
462 (Wipperman et al., this volume) shows turbidite and levee features, suggesting flow into the Nauru Basin from the southwest. The turbidites probably originated along the highly eroded northeast edge of the OntongJava Plateau. This plateau is marked by a major northsouth submarine valley into which pelagic carbonate sediments are carried by sliding and slumping. The sediments then move north. The Eocene chert below much of the plateau serves as a resistant floor along the sediment moves (Berger et al., 1977).

At Site 462, reef-derived skeletal debris (large benthic foraminifers, coralline algae, mollusks, bryozoans, and corals derived from reefs) was found in deep-water pelagic sediments of Oligocene, and middle Miocene age (Premoli Silva and Brusa, this volume), as shown in Figure 8.

In particular, the larger foraminifers recovered from Cores 21 through 34 are characteristic of the early Eocene, late Eocene, early Oligocene, and late Oligocene.

The occurrence of shallow-water Eocene fossils in deep-water Oligocene strata is probably the result of erosion of reefs in the Marshall Islands, northeast of Site 462. Schlanger and Douglas (1974) have pointed out that both Enewetak and Bikini Atolls were emergent during Oligocene time. Savin et al. (1975) have documented a severe drop in sea-surface temperatures begin-

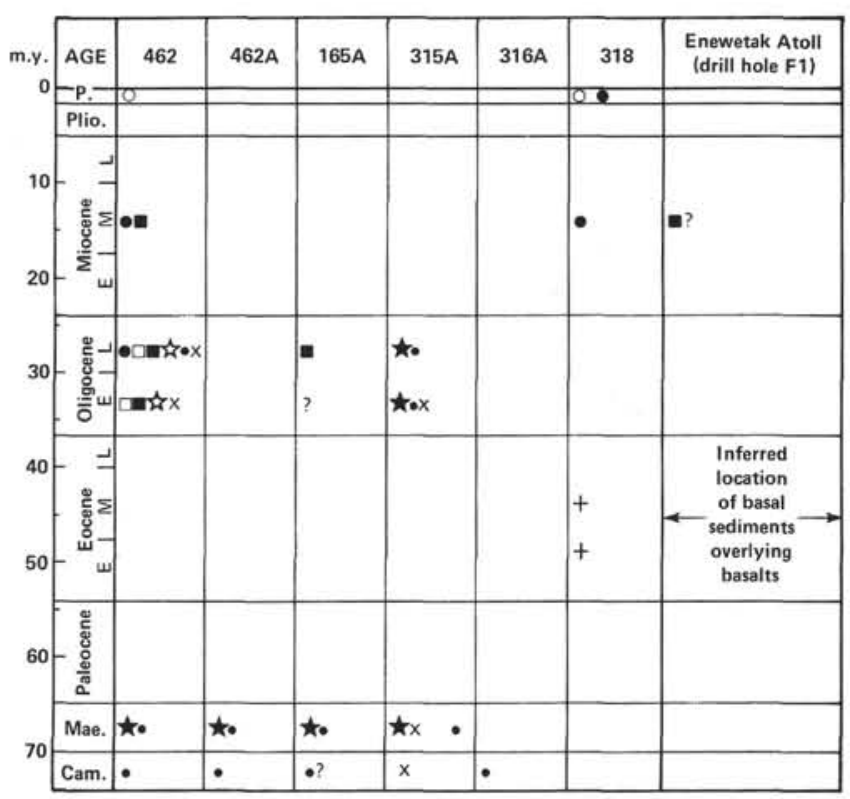

- PLIO-PLEISTOCENE: Amphisteginid-Miliolid assemblage

- LATE OLIGOCENE: Heterostegina-Nephrolepidina assemblage

- EARLY OLIGOCENE: Nummulites vascus $-N$. bouillei assemblage

- LATE EOCENE: Nummulites-Spiroclypeus-Asterocyclinid assemblage

+ LATE EARLY-MIDDLE EOCENE: Discocyclinid-Asterocyclid assemblage

A EARLY EOCENE: Nummulites-Assilina assemblage

$\star$ EARLY-MIDDLE MAESTRICHTIAN: Lepidorbitoides-Asterorbis assemblage

- LATE CAMPANIAN: Pseudorbitoides-Vaughanina assemblage

$\times$ MID-CRETACEOUS: Cuneolina-Orbitolinid assemblage

Figure 8. Stratigraphic distribution of displaced reef fauna at DSDP drill sites in the Nauru Basin, the Line Islands, and the Tuamotu Islands (from Premoli Silva and Brusa, this volume). 
ning in Eocene time and culminating in late Oligocene time, about $27 \mathrm{~m} . y$. ago. This date corresponds to a major phase of glaciation in the southern hemisphere, which would account for the major Oligocene sea-level fall and consequent erosion of Eocene reefs over much of the Pacific. This late Oligocene erosion caused redeposition of Late Cretaceous reef fossils into late Oligocene strata, testifying to the intensity of erosion. Finally, in middle Miocene time, 13 to $16 \mathrm{~m} . \mathrm{y}$. ago., a minor sea-level drop (see Schlanger and Douglas, 1974) resulted in some erosion of late Eocene assemblages from the Marshall Islands.

\section{CHRONOLOGY OF VOLCANIC EPISODES IN THE NAURU BASIN}

Any attempt at reconstructing the chronology of volcanism in the Nauru Basin must take the following arguments and data into account. For details, see the pertinent chapters in this volume, as cited below.

1) The stratigraphically lower unit in the volcanic complex is of sheet-flow origin. The interval occupied by these flows is from Core $462 \mathrm{~A}-60$ through Core $462 \mathrm{~A}-92$. The stratigraphically upper unit is made up of sills and occupies the interval from Core 462A-14 through Core 462A-42 (Batiza et al., this volume; Moberly and Jenkyns, this volume).

2) The lower flow unit was altered by hydrothermal circulation; this alteration is similar to the alteration of normal MORB. The sills were altered by fluids of high $P_{\mathrm{CO}_{2}}$ content, and also show evidence of late-magmatic alteration. A period of sedimentation occurred between these two alteration events (Batiza et al., this volume).

3) Paleomagnetic data show that both the lower flow unit and the upper sill unit are normally magnetized throughout. However, two groups of inclinations exist: $-51.8 \pm 7.2^{\circ}$ (paleolatitude range $26^{\circ}$ to $40^{\circ} \mathrm{S}$ ) in the upper sill complex, and $-38.1 \pm 6.6$ (paleolatitude range $17^{\circ}$ to $26^{\circ} \mathrm{S}$ ) for the lower flow unit. Therefore, two igneous events are recorded. The reversed interval in early Campanian time, between Anomalies 33 and 34, was detected in sediments deposited at a paleolatitude of $6.8 \pm 2.7^{\circ} \mathrm{S}$. This grades down to a paleolatitude of $8.4 \pm 3.7^{\circ} \mathrm{S}$ in Cenomanian sediments.

4) Organic-geochemistry studies (Thomson et al., this volume) show thermally mature hydrocarbons in Section 462-49-4 (early Maestrichtian, 70 m.y.), 46254-2 (Campanian, 70-78 m.y.), and 462-59-1 (late Albian, $\sim 100-105$ m.y.).

5) There is a systematic variation in chemical composition between the sills and the flows, which probably reflects differences between the two types in igneous petrogenetic processes (Batiza et al., this volume).

6) The flow unit contains hyaloclastite-rich radiolarian and agglutinated-foraminifer-bearing sediments of probable Barremian age (Core 462A-80, 115-121 m.y.; de Wever, this volume; Moberly and Jenkyns, this volume). These were laid down at bathyal depths.

7) The sills intrude late Albian to Cenomanian strata and therefore record an intrusion younger than 92 m.y.

8) The Cretaceous sediments contain substantial amounts of volcanically derived minerals of original hyaloclastite provenance (Moberly and Jenkyns, this volume). They also contain Aptian terrestrial plant debris, indicating nearby islands.

9) The late Campanian to early Maestrichtian volcaniclastic sediments contain reef fossils, indicating edifice-building on the flanks of the Nauru Basin.

10) Radiometric ages obtained by the ${ }^{40} \mathrm{Ar} /{ }^{39} \mathrm{Ar}$ method gave 120 m.y. $(462-60-1,65-69 \mathrm{~cm})$ for the upper sills, $110 \pm 3$ m.y. (462A-32-1, $46-49 \mathrm{~cm})$ for the upper sills, and 131 m.y. (462A-50-3, 130-134 cm) for the lower part of the sill complex (Ozima et al., this volume). J. Naughton of the Hawaii Institute of Geophysics obtained $127 \mathrm{~m} . \mathrm{y}$. (462A-32-1, 31-33 cm), $144 \pm 5$ m.y. (462A-50-3, 44-52 cm), and $134 \pm 12$ m.y. (462-69-105, $53 \mathrm{~cm})$, by the K/Ar method. The rocks have very low $\mathrm{K}$ contents, and taking into account comments of the analysts we consider the $110 \pm 3-\mathrm{m} . \mathrm{y}$. date as the most reliable.

11) Magnetic Anomaly M-26, on which Site 462 is located, is Oxfordian (148 m.y.) and fixes the age of the plate below the flow-and-sill complex.

With the points listed above in mind, scenarios of volcanism accounting for the evolution of the Nauru Basin can be developed. Moberly and Jenkyns (this volume) consider that the majority of evidence favors an interpretation involving three episodes of volcanism: (1) early Oxfordian, 148 m.y. ago, representing formation of the plate at a spreading ridge; (2) eruption of the sheet flows in Barremian time, 118 m.y. ago; and (3) emplacement of the sills in Campanian time, 75 m.y. ago. They also review other possible scenarios, including one in which four episodes are involved. However, in the interest of geological parsimony they conclude that their three-episode history is most probable. The paleomagnetic data are accounted for by postulating that the sheet-flow eruption took place during one of the normally magnetized periods in Barremian time (between M-2 and M-3, or M-4 and M-5). The sill event would have taken place between Anomalies 32 and 33 (Fig. 9).

Schlanger and Premoli-Silva (this volume) developed a four-episode volcanic history. They also take as the oldest event the formation of the underlying plate 148 m.y. ago. The next event was the eruption of sheet flows in Barremian time ( 115 m.y. ago) at bathyal depths, as evidenced by the radiolarian and agglutinated-foraminifer-bearing volcanogenic sediment in Core 462A-80 (deWever, this volume; Sliter, this volume). In this scenario, as in that of Moberly and Jenkyns (this volume), the normal magnetization of the flow unit was acquired between Anomalies M-2 and M-5. The third event is considered the main sill injection in Aptian time, dated by ${ }^{40} \mathrm{Ar} /{ }^{39} \mathrm{Ar}$ at $110 \mathrm{~m} . \mathrm{y}$. (Ozima et al., this volume). The abundance of Aptian plant remains in Section $462 \mathrm{~A}-40-1$, described by Jenkyns and Schlanger (this volume) indicates the growth of nearby edifices, in addition to the intrusion of sills. In this scenario, this sill emplacement took place during the Cretaceous longnormal event, which dates from 80 to $112 \mathrm{~m}$.y. ago (R. Larson, pers. comm.).

A fourth volcanic event is proposed by Schlanger and Premoli Silva (this volume) to have taken place in late Campanian to early Maestrichtian time. This event ther- 


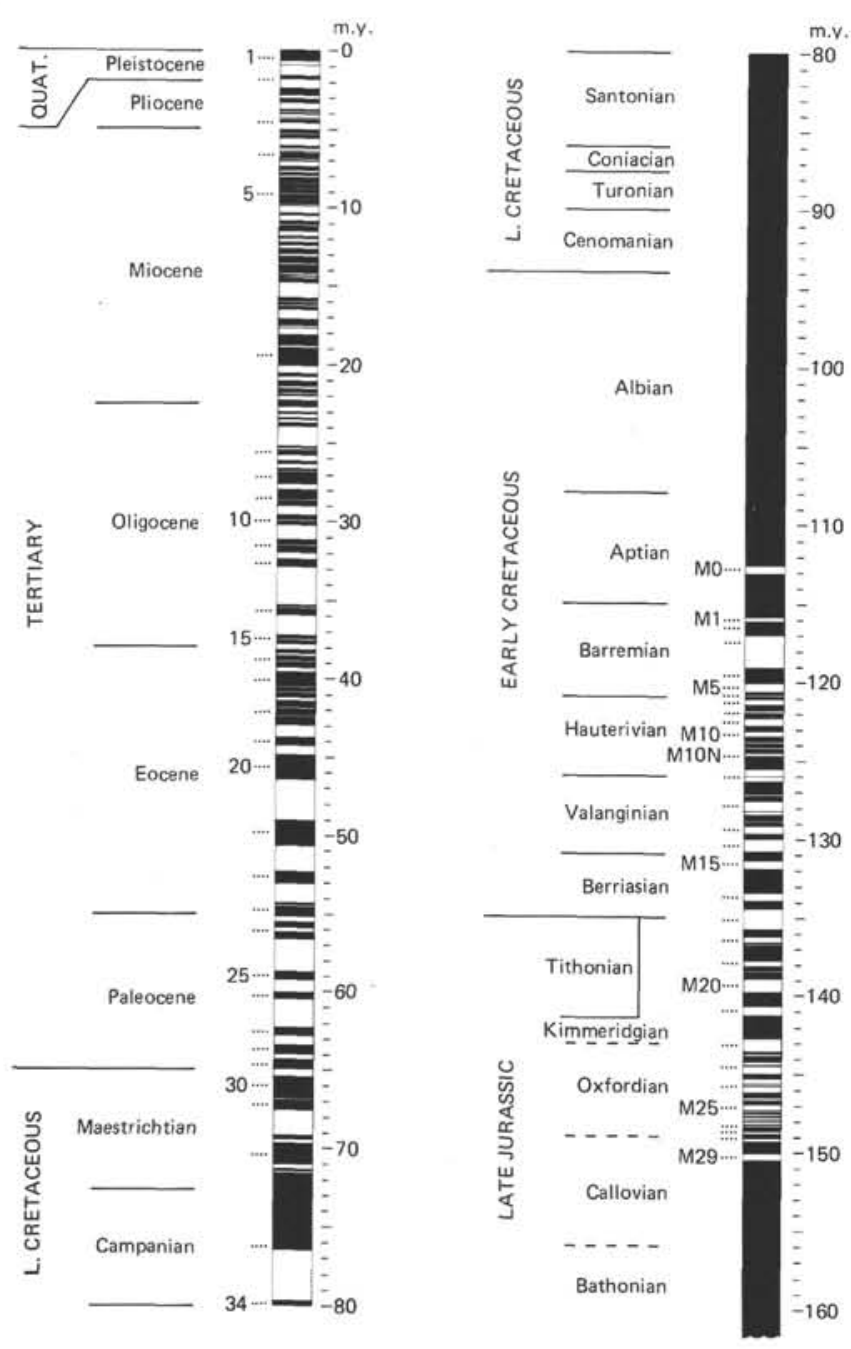

Figure 9. Time scale of magnetic-field reversals, derived from marine magnetic anomalies by LaBreque et al. (1977; 0-80 m.y.), and by Larson et al. (in prep.).

mally matured the hydrocarbons in Late Cretaceous sediments and, as evidenced by the presence of Campanian to Maestrichtian reef-derived fossils in these sediments, built edifices nearby into the euphotic zone. This event began about 76 m.y. ago, and culminated about $70 \mathrm{~m} . \mathrm{y}$. ago, during the normal magnetic epoch between Anomalies 32 and 33. This edifice-building event is also recorded in the Line Islands (Schlanger and Premoli Silva, this volume). This last event left a record of volcaniclastic and volcanic-ash-rich sediments over a wide area of the western Pacific basin (Rea and Thiede, this volume; Vallier and Rea, 1980).

The exact timing of the igneous eruptions obviously is not precisely known. It is unsettling that the entire igneous sequence is normally magnetized, but that the geology of Site 462 suggests eruptions during mixedpolarity intervals that pre-date and post-date the long Cretaceous normal interval. While not impossible, it is unlikely that eruptions occurred only in the normal intervals of time characterized by mixed magnetic polarity.

\section{THE CO-EXISTENCE OF JURASSIC MAGNETIC ANOMALIES AND THE CRETACEOUS VOLCANIC COMPLEX}

We argued above that the magnetic anomalies in this area are lineated and easily correlated with Late Jurassic reversal patterns. Site 462 is located between Anomalies M26 and M27; thus it has an initial, or plate, age of Oxfordian (148 m.y.). The 504 meters of volcanic rocks and sediments penetrated here range in age from Early to Late Cretaceous; these rocks are evidence for a volcanic event or events at least 30 m.y. younger than the oceanic crust. These two phenomena constitute a paradox which appears to characterize at least the entire Nauru Basin. The Cretaceous volcanic complex requires us to consider the magnetic, structural, and thermal problems associated with its existence and emplacement relative to the Jurassic basement. The possible problem of the remanent magnetization of the Cretaceous basalts obscuring the Jurassic anomaly pattern is explained, because it appears that the contribution of the Cretaceous volcanic complex to the magnetic-anomaly signal is very simple. All of these rocks recovered at Site $\mathbf{4 6 2}$ are normally magnetized, with, not identical, but relatively uniform inclination directions. If this uniform, normal magnetization holds for the Cretaceous volcanic complex throughout the Nauru Basin, the complex can be considered to be a uniformly magnetized sheet that will produce a magnetic anomaly only at its edges. In the terminology of Parker and Huestis (1974), it is a magnetic body with a magnetic annihilator of any constant value. Thus, any amount of uniformly magnetized basalt that overlies the original volcanic basement will not contribute to the magnetic-anomaly signal measured at the surface.

The emplacement of the Cretaceous volcanic complex through the Jurassic basement raises structural and thermal problems. It is not obvious how a sequence of volcanic material at least 500 meters thick can be emplaced through oceanic crust at least $30 \mathrm{~m} . \mathrm{y}$. old without destroying or radically attenuating the original magnetic-anomaly signature. The many chill zones and thin flow units, especially in the lower extrusive sequence, indicate that source vents for the Cretaceous basalts recovered at Site 462 were very near their present location. Thus, it is extremely unlikely that the majority of the basalts could have traveled large horizontal distances. The source vents are almost certainly within the detailed-site-survey area, characterized by undisturbed Late Jurassic magnetic anomalies. Thus, the evidence requires that Cretaceous magma be brought up through Jurassic crust in a manner that does not affect the indigenous magnetic signal by either structural or thermal effects.

The simplest and least-disruptive manner of fracturing the oceanic crust to provide magma conduits probably is tensional cracking associated with thermal uplift that accompanied the Cretaceous volcanic event. If this occurred as simple pull-apart rifts, with little or no dipslip displacement-such as those that have been ob- 
served at active ridge crests-it appears possible that the fracturing occurred without significant disruption of the magnetic structure of the country rock. The question that cannot be answered now is whether the tensional cracking occurred first as a result of thermal doming and uplift to create open passageways for the Cretaceous magma, or the Cretaceous magma actively wedged its way up to or near the surface by a process similar to hydrofracture. In the first case, tensional stress in the Jurassic basement results from thermal doming and uplift. This tensional stress generates simple, pull-apart rifts, similar to Icelandic gja, or rifts present at modern spreading centers. These rifts are then the conduits for Cretaceous magma.

While this is a possible mode of failure of the uppermost oceanic crust, it is an unlikely if not impossible mechanism for faulting deeper in the basement. If the magma source was several kilometers deep in the crust, the tensional stress would cause immediate failure by normal faulting, because the overburden or confining pressure would exceed the tensile strength of the rock (Anderson, 1951). In this case, the magma might move upward by a wedging process which requires only that the hydrostatic pressure in the magma chamber be slightly greater than the confining pressure of the Jurassic overburden, and the magma chamber walls to have minor irregularities. In this case, the confining pressure will be exceeded by a large horizontal tension that results from the shape of the initial cavity. A small initial cleft can be extended by this wedging effect, because the constant hydrostatic magma pressure becomes concentrated as a large, outward-directed force in a crack where the surface area per unit volume is maximized (Anderson, 1951). This is a process similar to that described by Weertman (1971) for water-filled cracks in glaciers, and by Aki and others (1977) for magma-filledcrack propagation associated with Hawaiian volcanic eruptions.

The heat generated by a volcanic event or events large enough to form the Nauru Basin complex is significant, and is an important consideration in the magnetic history of the Nauru Basin. Why was the Jurassic basement not thermally demagnetized by emplacement of the Cretaceous volcanic complex? Intuition leads one to suspect that conductive cooling of the Cretaceous dikes in the Jurassic basement would raise its temperature high enough, for a long enough time, to substantially alter the Jurassic magnetic signature. It has been shown by Ozima and Ozima (1971) and Lowrie (1974) that oceanic basalt can be almost completely demagnetized by heating in the laboratory to about $300^{\circ} \mathrm{C}\left(220-400^{\circ} \mathrm{C}\right.$ in Lowrie, 1974). At this temperature, the original titanomagnetite or titanomaghemite separates into $\mathrm{Ti}$ rich hemo-ilmenite and Ti-poor magnetite, and the thermomagnetic curve becomes irreversible. Heating oceanic basalt in situ should produce the same result, but it is not necessary to heat the basalt to $300^{\circ} \mathrm{C}$ to achieve demagnetization. The same effect can be produced if the rock is heated at lower temperatures for longer periods of time than in a laboratory experiment. McElhinny (1973) simplified the original equation of
Néel (1949) to the following expression for this relationship:

$$
T_{1} \ln C \tau_{1}=T_{2} \ln C \tau_{2}
$$

where $T_{1}, T_{2}=$ two different temperatures in ${ }^{\circ} \mathrm{K} ; \tau_{1}, \tau_{2}$ $=$ two different relaxation times in seconds; and $C=\mathrm{a}$ frequency factor $\simeq 10^{10} \mathrm{sec}^{-1}$.

The relaxation time is defined by $t=0.693 \tau$, where $t$ is the time in seconds when the magnetic moment has decayed to half its initial value, and thus can be thought of as the "half-life" of the initial remanence.

If the characteristic time of a laboratory heating experiment is about five minutes $\left(3 \times 10^{2} \mathrm{~s}\right)$, the foregoing expression can be used to calculate relaxation times corresponding to lower temperatures, as shown in Table 1 and Figure 10 (from Chamalain, 1964; and Briden, 1965).

That conductive heating will produce temperatures for times comparable to the blocking temperatures and extended relaxation times given in Table 1 was shown by

Table 1. Blocking temperature versus magnetic-moment relaxation time for oceanic basalt.

\begin{tabular}{|c|c|c|c|}
\hline $\begin{array}{c}\text { Blocking } \\
\text { Temperature, } T \\
\left({ }^{\circ} \mathrm{C}\right)\end{array}$ & $\begin{array}{l}\text { Relaxation } \\
\text { Time, } \tau\end{array}$ & $\ln \tau$ & $\frac{\ln \tau /}{\ln 10}=\log _{10} \tau$ \\
\hline 300 & $\min$. & 5.704 & 2.477 \\
\hline 250 & $78 \mathrm{~min}$. & 8.451 & 3.670 \\
\hline 200 & 1.51 days & 11.78 & 5.116 \\
\hline 150 & 92 days & 15.89 & 6.901 \\
\hline 100 & 46.66 yrs. & 21.11 & 9.168 \\
\hline 50 & $43,207 \quad$ yrs. & 27.94 & 12.134 \\
\hline
\end{tabular}

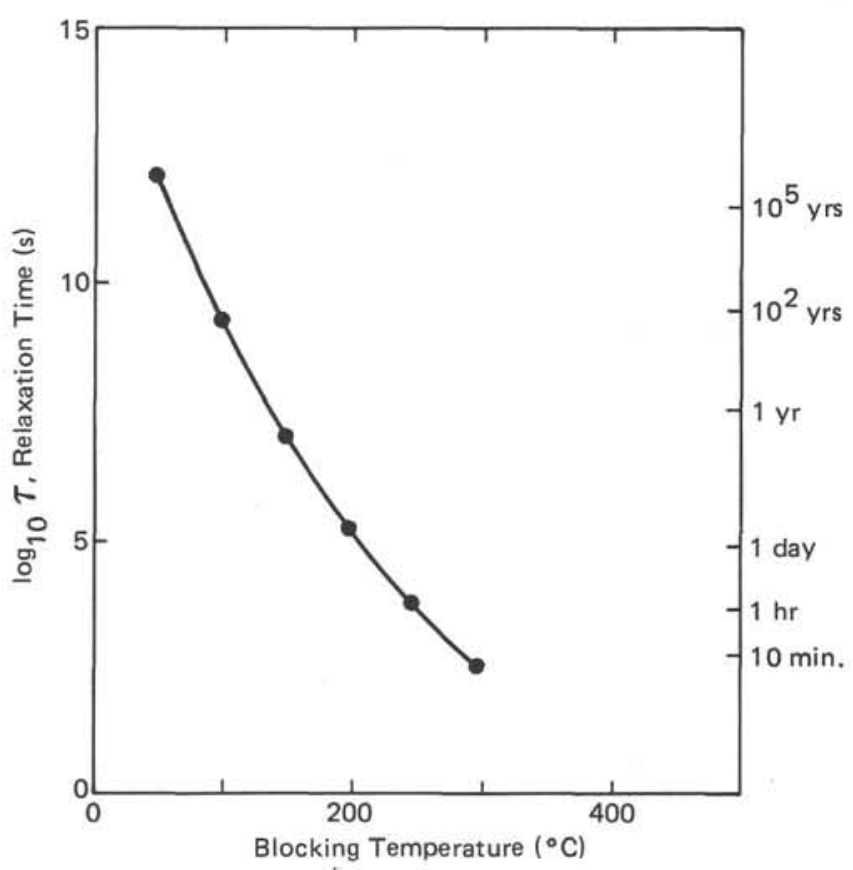

Figure 10. Variation in relaxation time with blocking temperature for oceanic basalt. 
Lovering (1935) for various intrusive bodies. His model of a dike assumed an intrusive body 20 meters wide, having a thermal diffusivity of average igneous rock $\left(h^{2}\right.$ $=0.012 ; h^{2}=k / c \varrho$, where $k$ is thermal conductivity, $c$ is specific heat, and $\varrho$ is the density of the substance).

These parameters can be varied within reasonable limits, but the general result is still applicable. Figure 11 (Lovering, 1935) shows the thermal-decrement curves for the dike described above, plotted as functions of the distance from the dike center and the square root of time subsequent to the intrusion. A point anywhere on this diagram thus represents the temperature of that point at a particular time subsequent to the intrusion. A cross-section parallel to the base represents the temperature profile at any time, while a perpendicular crosssection represents the temperature history of a given point adjacent to (or within) the dike. Thus, a perpendicular cross-section 40 meters from the center of the dike ( $30 \mathrm{~m}$ from the edge) shows that the temperature of this point would be raised to $10 \%$ of the initial temperature difference for 46.5 years (9.5 to 56 years) subsequent to the intrusion. If the initial temperature difference between the intrusion and the country rock is taken, for the sake of simplicity, at $1000^{\circ} \mathrm{C}$, then the $100^{\circ} \mathrm{C}\left(10 \%\right.$ of $\left.1000^{\circ} \mathrm{C}\right)$ temperature elevation for 46.5 years is nearly identical (a computational coincidence, in this case) to the relaxation time (Table 1) required to demagnetize the country rock if the blocking temperature is $100^{\circ} \mathrm{C}$.

This model considers only a single intrusive dike, and the Nauru Basin was likely characterized by multiple intrusions and numerous vents. Certainly Site 462 is close to the source vent or vents for the material recovered there. It would be an unlikely coincidence if this site was near the only Cretaceous feeder dike-or one of only a few feeder dikes-in the Nauru Basin. Thus, we assume that the Nauru Basin is pervaded by Cretaceous dikes. Jaeger (1964) showed in the case of multiple dike intrusions, where the bodies parallel each other that the

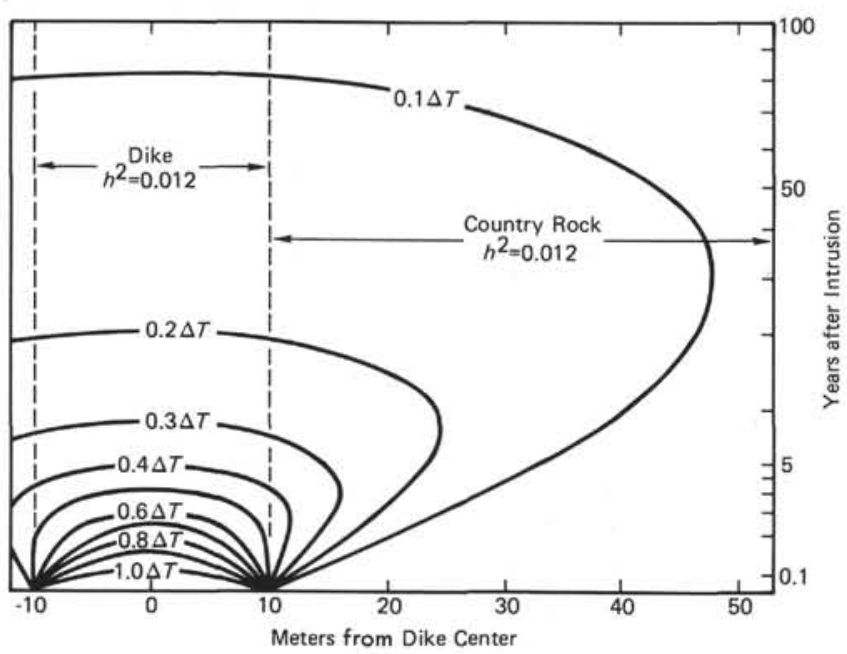

Figure 11. Temperature structure for 0 to 100 years after the instantaneous intrusion of a 20-meter-wide dike into igneous country rock. All material has a diffusivity, $h^{2}=0.012$. Thermaldecrement curves plotted as percentages of the original temperature difference, $\Delta T$. temperature distributions are additive at any given time subsequent to the dike intrusions. This consideration serves to re-enforce the conclusion that conductive heating, acting alone, would have thermally demagnetized a significant amount of the Nauru Basin's Jurassic basement.

Because conductive cooling of the Cretaceous dikes will thermally demagnetize a significant amount of the adjacent Jurassic basement, it appears that an additional heat-transfer process is required to remove heat more quickly from the structure. We suspect that the tension fractures and cracks required as conduits for the Cretaceous magma also allowed sea water deep access into the Jurassic oceanic crust. This water was in turn heated by the Cretaceous intrusions and carried away excess heat by convective cooling. While this hydrothermal circulation would remove heat in the required timely fashion, it also makes possible additional hydrothermal alteration of the Jurassic basement. However, it is likely that the principal carrier of the magnetic signal at this point was titanomaghemite produced at the $\mathrm{Ju}$ rassic ridge crest by ocean-floor weathering (Marshall and Cox, 1972), or regional hydrothermal alteration (Ade-Hall et al., 1971). If this was the case, it is unlikely that further degradation of the Jurassic magnetic signal would result from a hydrothermal regime similar to the one that the Jurassic crust was subjected to just after its formation.

\section{REGIONAL IMPLICATIONS OF NAURU BASIN VOLCANISM}

A survey of Cretaceous volcanism covering a large area of the central Pacific, (Schlanger and Premoli Silva, this volume) extending from the Nauru BasinMarshall Islands area on the west to the Line Islands on the east, and including the Mid-Pacific Mountains on the north (Figs. 12 and 13), shows that the entire region may have undergone uplift associated with sill intrusions and the buildup of seamounts and large subaerial volcanic edifices as a mid-plate volcanic phenomenon. This regional volcano-thermal event began in Barremian time with the extrusion of the sheet-flow unit, and intensified in Aptian time, about 110 m.y. ago, with sill intrusions and edifice-building. It continued into Late Cretaceous time, ending approximately $70 \mathrm{~m} . \mathrm{y}$. ago, when the Marshall Islands bore Campanian-Maestrichtian reefs. This interpretation of the vertical tectonic history of the area is similar to the evolution of the Darwin Rise described by Menard (1964) and incorporates elements of the model used by Hsü and Schlanger (1968), who related changing thermal regimes in the upper mantle to crustal uplift and subsidence history. Menard (1964) postulated the elevation of a broad swell in late Mesozoic time which he called the Darwin Rise, over an area which includes the area discussed in the present paper. He further called on volcanism on an enormous scale in Late Mesozoic time to form the MidPacific Mountains, the Line Islands, and the Marshall Islands, as well as many other island chains.

It is likely that the Nauru Basin also was involved in this late Mesozoic uplift and re-subsidence. Detrick and Crough (1978) and Crough (1978) have modeled sub- 


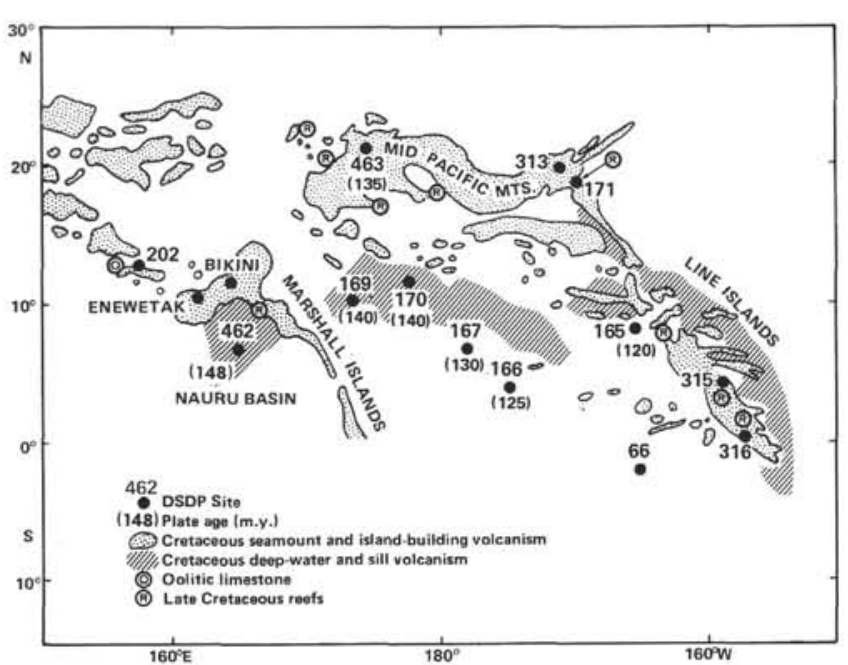

Figure 12. Areal distribution of Cretaceous mid-plate volcanism in the central Pacific, and Late Cretaceous reefs and oolitic limestone (modified from Winterer, 1973; Late Cretaceous reefs from various sources; oolitic-limestone locality from Heezen, MacGregor, et al., 1972).

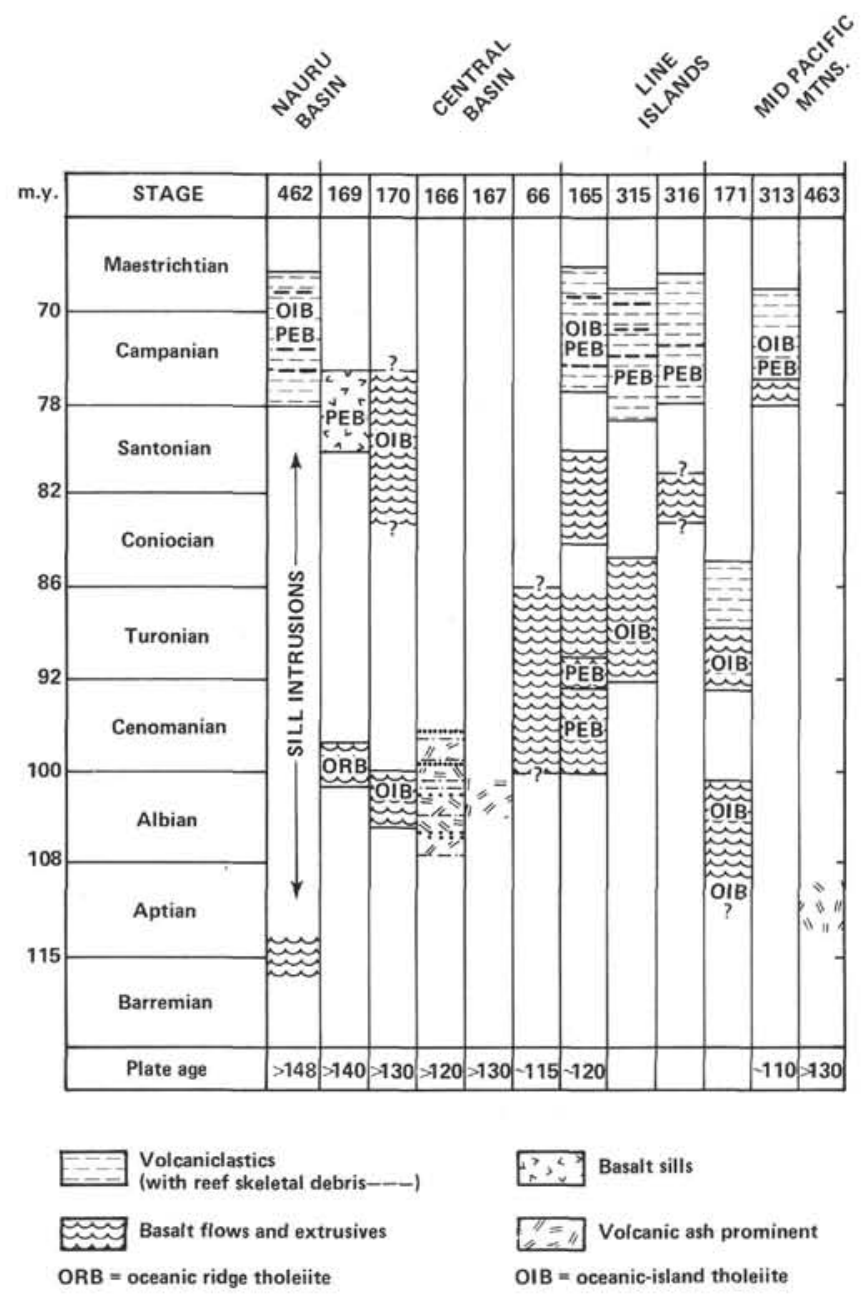

PEB $=$ post-erosion basalt

Figure 13. Stratigraphic distribution of Cretaceous mid-plate volcanic rocks at DSDP sites in the central Pacific (Schlanger and Premoli Silva, this volume). sidence in the Hawaiian and Marshall Islands as a result of lithospheric thinning that effectively resets the thermal age of the crust to about 25 m.y. The "seamount uplift" model curve shown in Figure 14 is based on the Detrick and Crough (1978) model corrected for additional subsidence of the Jurassic basement due to loading of the Cretaceous volcanic pile and subsequent sedimentation. The "no uplift" curve is a model that assumes that no thermal uplift accompanied the midCretaceous volcanic episode. The present-day end points of both curves were derived by first taking the known depth to the top of the Cretaceous volcanics $(5750 \mathrm{~m})$ and unloading $560 \mathrm{~m}$ of overlying sediment of average density $1.7 \mathrm{gm} / \mathrm{cc}$ to calculate an isostatically corrected depth of $5582 \mathrm{~m}$. This depth is then subtracted from the present-day depth of the normal subsidence curve $(6120 \mathrm{~m})$ and the seamount uplift curve $(5730 \mathrm{~m})$ that assumes a 25 m.y. thermal reset age at 70 m.y. ago and on subsequent loading. The differences $(538 \mathrm{~m}$ for normal subsidence and $148 \mathrm{~m}$ for seamount uplift) represent the "isostatic freeboard" of the top of the Cretaceous volcanics above particular model cooling curves. If the isostatic freeboards are known and a uniform density $(2.7 \mathrm{gm} / \mathrm{cc})$ is assumed for the entire Cretaceous volcanic pile, then the total thicknesses of the Cretaceous volcanics can be calculated to be $1990 \mathrm{~m}$ for the normal subsidence model and $547 \mathrm{~m}$ for the seamount uplift model. The minor amount of isostatic depression due to post-mid-Cretaceous sedimentation can be added back in, and the curves in Figure 6 then represent the vertical motion of Jurassic basement in the Nauru Basin for the past 150 m.y. that results from the assumptions of either no uplift or uplift to a $25 \mathrm{~m} . \mathrm{y}$. isobath during the mid-Cretaceous volcanic episode.

Since Site 462 bottomed in the mid-Cretaceous volcanic complex within $40 \mathrm{~m}$ of the present-day depth of the seamount uplift model curve, it appears that the Nauru Basin did not experience more uplift than that predicted for seamounts built on crust with a thermal reset age of $25 \mathrm{~m} . \mathrm{y}$. That is to say, that if the seamount uplift model is correct for the Nauru Basin, then Jurassic basement should lie just below $(40 \mathrm{~m})$ the total depth of Site 462. Intuition suggests that the actual amount of mid-Cretaceous uplift was something less than that experienced by seamount chains, so that the depth to Jurassic basement is probably somewhere in the bracketed range on Figure 6 that is bounded by both models. Figure 15 shows a graphic synthesis of the geologic history of the Nauru Basin based essentially on the seamount uplift model shown in Figure 14. As described above, this is merely an example of geologic history that includes a maximum amount of uplift. It is not a well-constrained model, because the depth to Jurassic basement remains unknown beneath the bottom of Site 462.

The widespread distribution of Cretaceous mid-plate volcanism in the Central Pacific leads to the conclusion that the concept of hot spots of Morgan (1972) does not account for this type of widespread, synchronous, and long-lived volcanism. One implication of the hot spot concept is that mid-plate volcanic activity due to plate motion over a hot spot should be restricted within a cir- 


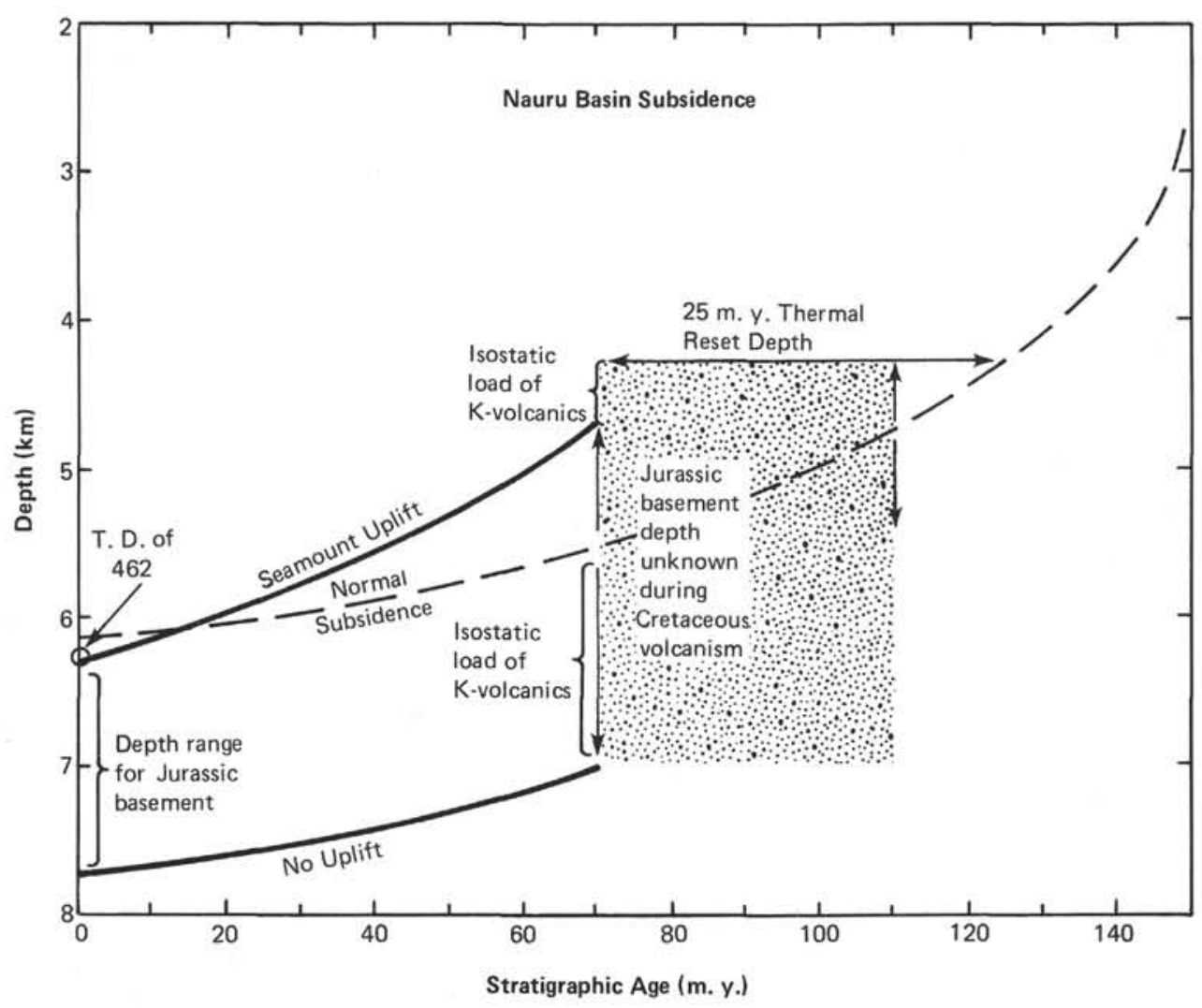

Figure 14. Vertical-motion models for Jurassic basement in the Nauru Basin (Schlanger and Premoli Silva, in press). "Smt-model uplift"' after Detrick and Crough (1978) assumes thermal age resetting of the lithosphere to $25 \mathrm{~m}$.y. during the Cretaceous volcanic event, isostatically corrected for subsequent sedimentation and the known 505 meters of Cretaceous volcanics at Site 462 . "No uplift" model assumes normal subsidence (also shown for reference) during the Cretaceous volcanic event, and isostatic depression due to the Cretaceous volcanics and subsequent sedimentation.

cle on the surface of the earth perhaps $200 \mathrm{~km}$ in diameter at any given time. This restriction on the areal extent of surficial volcanism derives from the fact that the linear island chains in the Pacific used to trace the path of the hot spots relative to the overriding plate can be enclosed by a band $200 \mathrm{~km}$ wide. A further implication is that the temporal extent of volcanism at any given point is limited by the velocity of the plate relative to the hot spot. Considering an average plate velocity of $\sim 10$ $\mathrm{cm} / \mathrm{yr}$ and a hot spot surface manifestation diameter of $200 \mathrm{~km}$, volcanism at one point in the plate should last on the order of 1 to $2 \mathrm{~m}$.y.

As shown in Figure 12, Central Pacific mid-plate volcanism took place over an area on the order of $10^{6}$ $\mathrm{km}^{2}$. Volcanism took place in the Nauru Basin and probably in the Line Islands and the eastern mid-Pacific Mountains and persisted, albeit intermittently, for $>40$ m.y., from Barremian (115 m.y.) and Aptian (110 m.y.) to Campanian-Maestrichtian time $(\sim 70$ m.y.). Attempts to explain the areal and temporal distribution of Late Cretaceous volcanism by applying the WilsonMorgan hot-spot model can lead to difficulty. For example, Winterer (1976), in trying to reconcile the sill age $(80-87$ m.y.) at Site 170 with simultaneous ( $80-85$ m.y.) cessation of volcanism at Site 165 , pointed out that a very rapid progression of volcanism between these sites must be assumed. He suggested a more attractive hypothesis that "would allow nearly simultaneous eruption of basalt over a broad region by having numerous, relatively short progressive chains operating in parallel" (Winterer, 1976, p. 742). Thus, to avoid very high progression rates, numerous hot spots are invoked, each making its own microchain. In avoiding the fast-progression difficulty, one is led to a new difficulty, involving the need for numerous hot spots, the surface expression of each being very short-lived. This short-lived attribute then is in contradiction to the original hot-spot idea, that Pacific hot spots are long-lived and produce chains as long as the Hawaiian-Emperor chain. Larson, Moberly, et al. (1975) also were unable to reconcile the history of the Mid-Pacific Mountains with a hot-spot origin. Jackson and Schlanger (1976) argued that the results of DSDP drilling along the Line Islands indicated that the hot-spot mechanism could not be applied to that large chain.

Thinking in terms of individual, areally restricted hot spots leads only to greater difficulties and an ever more complicated scheme as our data base expands. It appears unlikely that the hot-spot mechanism is the only way to account for Cretaceous mid-plate volcanism in the central Pacific. Perhaps potential extrusive magmas underlay the lithosphere across the entire central Pacific from Barremian-Aptian to Campanian-Maestrichtian time. The problem of Cretaceous mid-plate volcanism is reduced then to finding a mechanism that would allow the magmas access to the surface. 


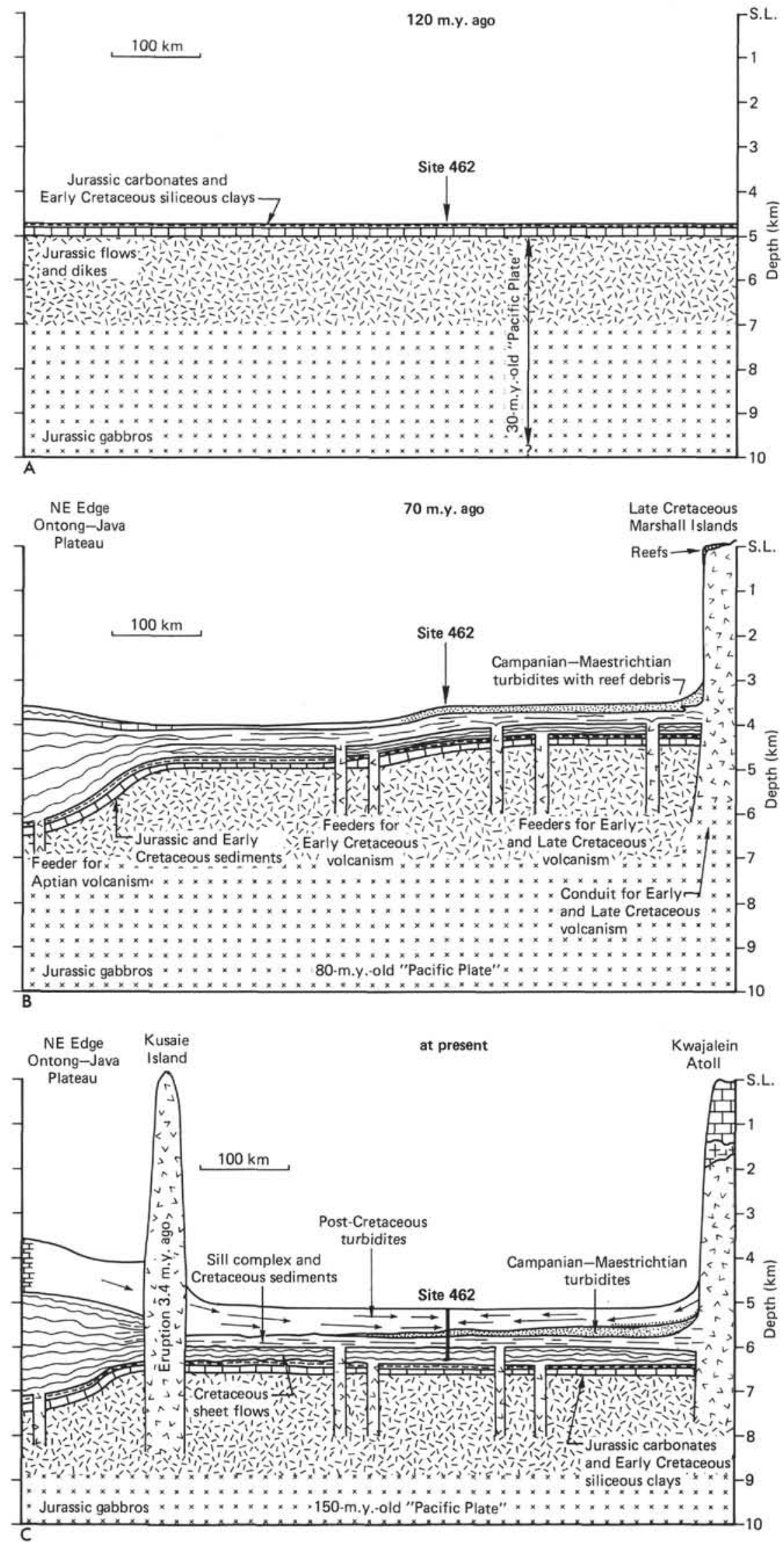

Figure 15. Geologic evolution of the Nauru Basin. Sections are drawn parallel to Magnetic Anomaly M-26. A. Nauru Basin 120 m.y. ago. B. Nauru Basin 70 m.y. ago. C. Nauru Basin at present. 
The uplift of much of the central Pacific in Cretaceous time because of mid-plate volcano-thermal events contributed to the major global Cretaceous sea-level rise (e.g., Vail et al., 1977). Therefore, changes in spreading rates along rise crests (Hays and Pitman, 1973; see Pitman, 1978 for a review) may not have been the only major factor that produced the great Cretaceous transgressions; epeirogenic, thermally-induced regional uplift also may have contributed (Schlanger et al., 1981). The sea-level curve of Vail et al. (1977) shows the global Cretaceous transgression correlated with widespread Barremian-Aptian to early Maestrichtian volcanism. The Nauru Basin evidently had a history similar to that of the Caribbean Basin, whose shallow depth and thick underlying crust has been attributed to the large-scale intrusion of sills approximately 80 m.y. ago (Burke et al., 1978). Indeed, results of Leg 61 reinforce the argument of other workers that the Caribbean was originally part of the Farallon Plate in Late Cretaceous time. The recent work of Kumar (1979) in the Atlantic shows that "excessive" volcanism between 100 and 80 m.y. ago may have formed the Rio Grande-Walvis Ridge system of paired aseismic ridges. If the Caribbean and Atlantic volcanic events also resulted in uplift, then they also would have contributed to the Cretaceous transgressions.

During Aptian-Albian time, Pacific reef faunas had Tethyan affinities, which is not surprising, because Cretaceous rudist reefs and their associated faunas appear to have been cosmopolitan at low latitudes. As pointed out by Beckmann (1976), the Campanian-Maestrichtian shallow-water reef foraminifers from the Line Islands show Caribbean affinities. The presence of an identical fauna at Site 462 (Premoli Silva and Brusa, this volume) extends the Caribbean bioprovince west to the Marshall Islands. Although the orbitoidid and similar faunas easily may have migrated where closely spaced shallow "stepping stones" were available, it is doubtful that they could quickly migrate across a large, deep ocean, such as the present eastern Pacific. The rapid colonization of the Line and Marshall Island areas by Caribbean-equivalent shallow-water reef faunas can be explained by postulating a Campanian-Maestrichtian paleogeographic reconstruction in which the present $\mathrm{Ca}$ ribbean Plate was close to those segments of the Pacific Plate on which the Line and Marshall Islands formed.

Several workers have interpreted the Caribbean as originally having been part of the Farallon Plate (Malfait and Dinkelman, 1972; Edgar et al., 1971). Mattson (1969) argued that the Caribbean was a detached relic of Darwin Rise. The similarities between the Caribbean and the Nauru Basin are striking. Both areas contain sill complexes of Cretaceous age (Burke et al., 1978), and the geochemistry of the sill complexes is similar (Batiza et al., this volume). The affinities between the Caribbean and Line Islands-Nauru Basin Cretaceous faunas substantiates the idea that the Caribbean and Nauru Basin areas are related and were closer together in Late Cretaceous time.

The Tertiary reef faunas from the Nauru Basin-Marshall Island area and the Line Islands (see Premoli-Silva and Brusa, this volume) show strong affinities with the Indo-Pacific faunas, and also with those of regions far- ther away, such as the Tethys. Nummulites burdigalensis, $N$. problematicus, $N$. sp. aff. $N$. variolarius, and Assilina leymeriei are also described from the Mediterranean area. It appears that the direction of colonization of the Marshall and Line Islands area was from east to west during Late Cretaceous time, but reversed (becoming west to east) during the Tertiary; the latter dispersal direction prevails at present. This shift can be explained by the growth since Late Cretaceous time of a large, deep eastern Pacific basin, which cut off colonization from the east, and the formation of numerous stepping stones in the western Pacific by early Tertiary volcanism, such as the last phase of volcanic activity at Enewetak in Eocene time, which allowed colonization eastward from the Indo-Pacific dispersal center.

\section{ACKNOWLEDGMENTS}

We thank both the scientists who served as our shipmates and those who acted as shore-laboratory investigators for their thorough and precise studies. Their works have shed new light on the various aspects of Cretaceous mid-plate volcanism. We have summarized many of these findings here and refer the reader to the more complete works described in the previous chapters. Our contributions to this chapter have been mainly to the latter sections on the coexistence of Jurassic magnetic anomalies with the Cretaceous volcanic complex and the regional aspects of Nauru Basin volcanism.

\section{REFERENCES}

Ade-Hall, J. M., Palmer, H. C., and Hubbard, T. P., 1971. The magnetic and opaque petrologic response of basalts to regional hydrothermal alteration. Geophys. J. Royal Astron. Soc., 24:137-174.

Aki, K., Fehler, M., and Das, S., 1977. Source mechanism of volcanic tremor: fluid-driven crack models and their application to the 1963 Kilauea eruption. J. Volcanol. Geothermal Res., 2:259-287.

Anderson, E. M., 1951. The Dynamics of Faulting and Dyke Formation with Applications to Britain (2nd ed.): Edinburgh and London (Oliver and Boyd).

Ballard, R. K., Holcomb, R. T., and van Andel, Tj. H., 1979. The Galapagos rift at $86^{\circ} \mathrm{W} .3$. Sheet flows, collapse pits and lava lakes of the rift valley. J. Geophys. Res., 84:5407-5422.

Batiza, R., Larson, R. L., Schlanger, S. O., et al., 1980. Trace element abundances in basalts Nauru Basin (DSDP Leg 61): Late Cretaceous off-ridge volcanism in the western Pacific. Nature, 286:476-478.

Beckmann, J. P., 1976. Shallow water foraminifers and associated microfossils from Sites 315,316 and 318 , DSDP Leg 33. In Schlanger, S. O., Jackson, E. D., et al., Init. Repts. DSDP, 33: Washington (U.S. Govt. Printing Office), 467-490.

Briden, J. C., 1965. Ancient secondary magnetization in rocks. $J$. Geophys. Res., 70:5205-5221.

Burke, K., Fox, P. J., and Sengör, A. M. C., 1978. Buoyant ocean floor and the evolution of the Caribbean. J. Geophys. Res., 83:3949-3954.

Cande, S. C., Larson, R. L., and LaBrecque, J. L., 1978. Magnetic lineations in the Pacific Jurassic quiet zone. Earth Planet. Sci. Lett., 41:434-440.

Chamalain, F. H., 1964. Origin of the second magnetization of the Old Red Sandstones of the Anglo-Welsh Curvette. J. Geophys. Res., 69:4327-4337.

Crough, T. S., 1978. Thermal origin of mid-plate hotspot swells. Geophys. J. Royal Astron. Soc., 55:451-469.

Detrick, R. S., and Crough, T. S., 1978. Island subsidence, hotspots and lithospheric thinning. J. Geophys. Res., 83:1236-1244.

Edgar, N. T., Ewing, J. I., and Hennion, J., 1971. Seismic refraction and reflection in the Caribbean Sea. Bull. Am. Assoc. Petrol. Geol., 55:833-870.

Einsele, G., Gieskes, G. M., Curray, J., et al., 1979. Intrusion of a basaltic sill into highly porous sediments, and resulting hydrothermal activity. Nature, 283:441-445.

Hammond, S. R., Kroenke, L. W., and Theyer, F., 1975. Northward motion of the Ontong-Java Plateau between -100 and -30 m.y.: a paleomagnetic investigation of DSDP Site 289. In Andrews, 
J. E., Packham, G., et al., Init. Repts. DSDP, 20: Washington (U.S. Govt. Printing Office), 415-418.

Hayes, D. E., and Rabinowitz, P. D., 1975. Mesozoic magnetic lineations and the magnetic quiet zone off northwest Africa. Earth Planet. Sci. Lett., 28:105-115.

Hays, J. D., and Pitman, W. C. III, 1973. Lithospheric plate motion, sea level changes and climates and ecological consequences. Nature, 246:18-22.

Heezen, B. C., MacGregor, 1. D., et al., 1972. Init. Repts. DSDP, 20: Washington (U.S. Govt. Printing Office), 97-105.

Heirtzler, J. R., and Hayes, D. E., 1967. Magnetic boundaries in the North Atlantic Ocean. Science, 157:185-187.

Howarth, M. K., 1964. The Jurassic period. Quart. J. Geol. Soc. London, 1205:203-205.

Hsü, K. J., and Schlanger, S. O., 1968. Thermal history of the upper mantle and its relation to crustal history of the Pacific Basin. Proc. XXIII Internat. Geol. Cong., 1:91-105.

Jackson, E. D., and Schlanger, S. O., 1976. Regional syntheses, Line Islands Chain, Tuamotu Island Chain, and Manihiki Plateau, Central Pacific Ocean. In Schlanger, S. O., Jackson, E. D., et al., Init. Repts. DSDP, 33: Washington (U.S. Govt. Printing Office), 915-927.

Jaeger, J. C., 1964. Thermal effects of intrusions. Rev. Geophys., 2:443-466.

Jenkyns, H. C., 1976. Sediments and sedimentary history, Manihiki Plateau, South Pacific Ocean. In Schlanger, S. O., Jackson, E. D., et al., Init. Repts. DSDP, 33: Washington (U.S. Govt. Printing Office), 873-890.

Kumar, N., 1979. Origin of "paired" aseismic rises: Ceara and Sierra Leone Rises in the equatorial, and the Rio Grande Rise and Walvis Ridge in the South Atlantic. Mar. Geol., 30:175-191.

LaBrecque, J. L., Kent, D. V., and Cande, S. C., 1977. Revised magnetic polarity time scale for the Cretaceous. Geology, 5:330-335.

Lancelot, Y., Hathaway, J. C., and Hollister, C. D., 1972. Lithology of sediments from the Western North Atlantic, Leg XI, Deep-Sea Drilling Project. In Hollister, C. D., Ewing, J. I., et al., Init. Repts. DSDP, 11: Washington (U.S. Govt. Printing Office), 901949.

Lancelot, Y., and Larson, R. L., 1975. Sedimentary and tectonic evolution of the northwestern Pacific. In Larson, R. L., Moberly, R., et al., Init. Repts. DSDP, 32: Washington (U.S. Govt. Printing Office), 925-939.

Larson, R. L., 1976. Late Jurassic and Early Cretaceous evolution of the western Pacific Ocean. J. Geomagnet. Geoelec., 28:219-236.

Larson, R. L., and Chase, C. G., 1972. Late Mesozoic evolution of the western Pacific Ocean. Geol. Soc. Am. Bull., 83:3627-3644.

Larson, R. L., and Hilde, T. W. C., 1975. A revised time scale of magnetic reversals for the Early Cretaceous and Late Jurassic. $J$. Geophys. Res., 80:2586-2594.

Larson, R. L., and Pitman, W. C. III, 1972. World-wide correlation of Mesozoic magnetic anomalies and its implications. Geol. Soc. Am. Bull., 83:3645-3662.

Larson, R., Moberly, R., et al., 1975. Init. Repts. DSDP, 32: Washington (U.S. Govt. Printing Office).

Lovering, T. S., 1935. Theory of heat conduction applied to geological problems. Geol. Soc. Am. Bull., 46:69-94.

Lowrie, W., 1974. Oceanic basalt magnetic properties and the Vine and Matthews hypothesis. Geophys. J., 40:513-536.

McElhinny, M. W., 1973. Paleomagnetism and Plate Tectonics: London (Cambridge Univ. Press).

Malfait, B. T., and Dinkelman, 1972. Circum-Caribbean tectonics and igneous activity and the evolution of the Caribbean Plate. Geol. Soc. Am. Bull., 83:251-271.

Marshall, M., and Cox, A., 1972. Magnetic changes in pillow basalt due to sea-floor weathering. J. Geophys. Res., 77:6459-6469.

Mattson, P. H., 1969. The Caribbean: a detached relic of the Darwin Rise. Am. Geophys. Union Trans., 50:317.

Menard, H. W., 1964. Marine Geology of the Pacific: New York (McGraw-Hill).

Morgan, J. W., 1972. Convection plumes and plate motions. Bull. Am. Assoc. Petrol. Geol., 56:203-213.

Muehlenbachs, K., 1980. The alteration and aging of the basaltic layer of the sea floor: oxygen isotopes evidence from DSDP/IPOD Legs 51, 52 and 53. In Donnelly, T., Francheteau, J., Bryan, W.,
Robinson, P., Flower, M., Salisbury, M., et al., Init. Repts. $D S D P, 51,52,53$, Pt. 2: Washington (U.S. Govt. Printing Office), 1159-1167.

Muehlenbachs, K., and Clayton, R. N., 1972. Oxygen isotope studies of fresh and weathered submarine basalts. Can. J. Earth Sci., 9:172-184.

Natland, J. H., 1976. Petrology of volcanic rocks dredged from seamounts in the Line Islands. In Schlanger, S. O., Jackson, E. D., et al., Init. Repts. DSDP, 33: Washington (U.S. Govt. Printing Office), $749-778$.

Néel, L., 1949. Theorie du trainage magnetique des ferromagnetiques au grains fins avec applications au terres cuites. Ann. Geophys., 5:99-136.

Ozima, M., and Ozima, M., 1971. Characteristic thermomagnetic curve in submarine basalts. J. Geophys. Res., 76:2051-2056.

Parker, R. L., and Huestis, S. P., 1974. The inversion of magnetic anomalies in the presence of topography. J. Geophys. Res., 79: 1587-1593.

Parsons, B., and Sclater, J. C., 1977. An analysis of the variation of ocean floor bathymetry and heat flow with age. J. Geophys. Res., $82: 803-827$.

Pitman, W. C. III, 1978. Relationship between eustatic and stratigraphic sequences of passive margins. Geol. Soc. Am. Bull., 89:1389-1403.

Savin, S. M., Douglas, R. G., and Stehli, F. G., 1975. Tertiary marine temperature. Geol. Soc. Am. Bull., 86:1499-1510.

Schlanger, S. O., 1963. Subsurface geology of Eniwetok Atoll. U.S. Geol. Survey Prof. Paper, 260-BB:901-1066.

Schlanger, S. O., and Douglas, R. G., 1974. The pelagic ooze-chalklimestone transition and its implications for marine stratigraphy. In Hsü, K. J., and Jenkyns, H. C. (Eds.), Pelagic Sediments on Land and under the Sea: Internat. Assoc. Sedimentol. Spec. Pub., 1:117-148.

Schlanger, S. O., Jenkyns, H. C., and Premoli-Silva, I., 1981. Volcanism and vertical tectonics in the Pacific Basin related to the global Cretaceous transgression. Earth Planet. Sci. Lett., 52:435449.

Siesser, W. G., 1978. Leg 40 results in relation to continental shelf and onshore geology. In Bolli, H. M., Ryan, W. B. F., et al., Init. Repts. DSDP, 40: Washington (U.S. Govt. Printing Office), 965-979.

Vail, P. R., Mitchum, R. M., Jr., and Thompson, S., 1977. Seismic stratigraphy and global changes in sea level. Part 4. Global cycles of relative sea level changes. Am. Assoc. Petrol. Geol. Mem., 26:83-98.

Vallier, T. L., and Rea, D. K., 1980. Cretaceous volcanic episodes in the western Pacific Ocean: a synethesis of Deep Sea Drilling results. Abs. Prog., 1980 Ann. Mts. Geol. Soc. Am., Nov. 17-20, 1980, Atlanta, Georgia., 12:539.

van Hinte, J. E., 1976a. A Jurassic time scale. Bull. Am. Assoc. Petrol. Geol., 60:489-495.

1976b. A Cretaceous time scale. Bull. Am. Assoc. Petrol. Geol., 60:497-576.

Vogt, P. R., Anderson, C. N., Bracey, D. R., and Schneider, E. D., 1970. North Atlantic magnetic smooth zones. J. Geophys. Res., 75:3955-3966.

Vogt, P. R., Anderson, C. N., and Bracey, D. R., 1971. Mesozoic magnetic anomalies, sea-floor spreading, and geomagnetic reversals in the southwestern North Atlantic. J. Geophys. Res., 76: 4796-4823.

Watts, A. B., Bodine, J. H., and Ribe, N. M., 1980. Observations of flexure and the geological evolution of the Pacific Ocean Basin. Nature, 283:532-537.

Weertman, J., 1971. Theory of water-filled crevasses in glaciers applied to vertical magma transport beneath oceanic ridges. J. Geophys. Res., 76:1171-1183.

Winterer, E. L., 1973. Regional problems. In Winterer, E. L, Ewing, J. I., et al., Init. Repts. DSDP, 17: Washington (U.S. Govt. Printing Office), 911-922.

, 1976. Bathymetry and regional tectonic setting of the Line Islands Chain. In Schlanger, S. O., Jackson, E. D., et al., Init. Repts. DSDP, 33: Washington (U.S. Govt. Printing Office), 731-748. 